Florida International University FIU Digital Commons

3-23-1998

\title{
Grandfamilies--Grandchildren raised by Grandparents: Impact on students and school services
}

Oliver Wayne Edwards

Florida International University

DOI: $10.25148 /$ etd.FI15101269

Follow this and additional works at: https://digitalcommons.fiu.edu/etd

Part of the Educational Administration and Supervision Commons

\section{Recommended Citation}

Edwards, Oliver Wayne, "Grandfamilies--Grandchildren raised by Grandparents: Impact on students and school services" (1998). FIU Electronic Theses and Dissertations. 3276.

https://digitalcommons.fiu.edu/etd/3276 


\title{
FLORIDA INTERNATIONAL UNIVERSITY
}

\author{
Miami, Florida
}

GRANDFAMILIES--GRANDCHILDREN

RAISED BY GRANDPARENTS:

IMPACT ON STUDENTS AND SCHOOL SERVICES

A dissertation submitted in partial satisfaction of the requirements for the degree of

DOCTOR OF EDUCATION

I N

EDUCATIONAL ADMINISTRATION AND SUPERVISION:

PSYCHOLOGY COGNATE

b $\mathbf{y}$

Oliver Wayne Edwards 
To: Dean Ira Goldenberg

College of Education

This dissertation, written by Oliver Wayne Edwards, and entitled Grandfamilies--Grandchildren Raised by Grandparents: Impact on Students and School Services, having been approved in respect to style and intellectual content, is referred to you for judgment.

We have read this dissertation and recommend that it be approved.

Stephen Fain
Allen Fisher
Barry Greenberg
Peter J. Cistone, Major Professor

Date of Defense: March 23, 1998

The dissertation of Oliver Wayne Edwards is approved.

Dean Ira Goldenberg

College of Education

Dr. Richard L. Campbell

Dean of Graduate Studies

Florida International University, 1998 
C COPYRIGHT 1998 by Oliver Wayne Edwards

All rights reserved 
I dedicate this dissertation to my wife, Pamela and daughters, Jasmine, Rebekah, and Misha, a family so caring and supportive that it made the considerable effort expended in completion of this work seem all the more gratifying. 


\section{ACKNOWLEDGMENTS}

I wish to thank the members of my committee for their helpful comments and assistance. I also wish to thank the school psychologists, social workers, and guidance counselors who helped with the data collection. I am deeply grateful to the grandparents who consented to participate in the study and the teachers who completed each 30-minute Teacher Report Form. Without these individuals, this study would not have been accomplished. Finally, particular appreciation is extended to my major professor, Professor Cistone, for his promptness in returning my drafts, his scholarly advice, and his role in the formulation of the school-based focus of this dissertation. 


\section{ABSTRACT OF DISSERTATION \\ GRANDFAMILIES--GRANDCHILDREN \\ RAISED BY GRANDPARENTS: \\ IMPACT ON STUDENTS AND SCHOOL SERVICES \\ b $\mathbf{y}$}

Oliver Wayne Edwards

Florida International University, 1998

Miami, Florida

Professor Peter J. Cistone, Major Professor

Historically, some grandparents have had to assume the responsibility for raising their grandchildren. More recently, with increasing frequency grandparents are serving as full-time surrogate parents to their grandchildren.

The term "grandfamily" was coined by this researcher to identify families where children are raised by grandparents. "Supergrands" are the grandparents and "grandkin" are children in these families. Supergrands who raise their grandkin tend to have elevated levels of stress that negatively impact their well-being. 
Grandkin tend to develop problems with attachment and establishing social networks, which can lead to poor psychological adjustment. School personnel believe grandkin evidence behavioral problems and occupy disproportionate amounts of their time each day. However, there is a dearth of data to support this belief.

This study empirically investigated the impact of grandfamilies on students and school services. The results revealed grandkin experienced significantly greater levels of emotional and behavior problems than similar schoolmates. However, they were not referred for discipline problems in substantially larger numbers.

These results indicate the practice of education should change to allow for the development and provision of social support procedures in schools. Social support will serve to buffer the stress, manifested in emotional and behavioral problems, encountered by children living with surrogate parents. A case study was presented along with a proposed intervention project that has potential to ameliorate the problems experienced by grandfamilies. 
I. AN EMERGING PHENOMENON

Introduction .......................................................

Definition of Terms ................................................... 2

The Formation of Grandfamilies .......................... 4

Statement of the Problem .................................... 7

The Plight of Encore Parenting ............................. 10

Purpose of the Study .................................................. 14

Statement of Hypotheses ....................................... 16

Limitations of the Study ......................................... 17

Organization of the Remaining Chapters .............. 19

II. REVIEW OF THE LITERATURE

Introduction ......................................................... 20

Demographics ...................................................... 20

The Grandparent Role ............................................ 27

Gender Issues and Grandparents ...................... 30

Cultural Factors ....................................................... 31

Adjustment Issues and Grandparents .............. 32

Grandparents' Experience .................................... 35

Grandchildren's Experience ................................... 36

Developmental Issues and Children .................... 39

Perspective of School Professionals .................... 44

Children in Foster care ........................................... 49

Theoretical Bases for the Study ............................. 57

Impact of Attachment and Social Support on

Students .................................................................. 59

\section{RESEARCH DESIGN AND METHODOLOGY}

Introduction .......................................................... 63

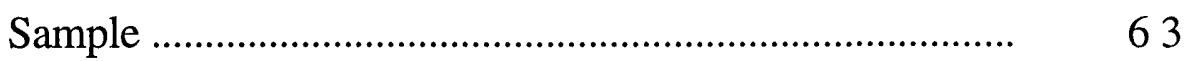

Study Instruments ............................................ 67

Procedures .......................................................... $\quad 70$ 
IV. DATA ANALYSIS

Introduction .......................................................

Results ....................................................................

V. DISCUSSION

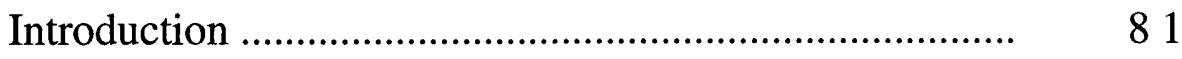

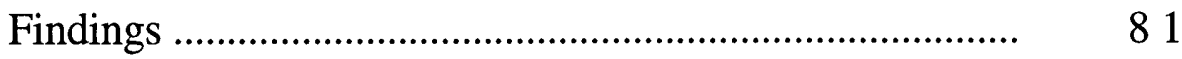

Academic Problems ………………………………...... $\quad 87$

Home Problems ............................................................. 89

The Grandfamily School Support Network ............ 92

Directions For Future Research ………...................... 99

Conclusion .......................................................................... 101

VI. A CASE STUDY

Introduction ................................................................ 103

Evaluation Instruments ................................................ 104

Background Information ............................................ 104

Behavioral Perspective ................................................ 106

Teacher Interview ........................................................... 108

Researcher Observation ............................................. 110

Intellectual Results .......................................................... 111

Academic Results …………………………………........ 115

Psychological Functioning ………………………......... 117

Case Study Summary .................................................. 120

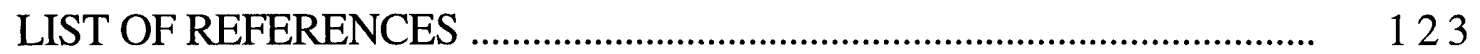




\section{LIST OF TABLES}

1. Supergrands' (Grandparents) Demographic Data ............ 65

2. Biological Parents' Demographic Data ................................. 65

3. Grandkin's Demographic Data and Comparison Group's Demographic Data ...................... 66

4. Means For Internalizing-T-scores ........................................ 77

5. Means For Externalizing-T-scores ...................................... 78

6. Effect For Group Multivariate Tests of Significance ......... 78

7. Effect For Group With univariate F-tests with ................. 78

8. Relationship Between Group Membership and Clinical Significance of Total Behavior Problems on the TRF ........ 79

9. Relationship Between Group Membership and Discipline Referrals ................................................................... 80

10. WISC-III IQ Scores Summary ................................................ 114

11. WISC-III IQ Subtest Scores Summary ................................ 115

12. WJ-R Academic Broad Scores .................................................. 116

13. WJ-R Academic Subtest Scores ............................................... 117 


\section{LIST OF FIGURES}

FIGURES

PAGE

1. Ethnic Data on Grandfamilies ............................................ 22

2. Supergrands and Grandkin in Broward ......................... 23

3. Ages of Grandkin Living in Broward ............................... 23

4. Grandkin Per Grandfamily in Broward ......................... 24

5. Supergrands' Educational Degree Status ......................... 25

6. Grandfamily Income in Broward .................................... 26

7. Composition of Heads of Households for

Grandfamilies in Broward County, Florida ..................... 27 


\section{CHAPTER I}

\section{AN EMERGING PHENOMENON}

\section{Introduction}

"Grandma, will I ever see mommy again?" These sad words illustrate the pain felt by an elementary school girl who was suffering through the breakdown of her nuclear family. This young child and her brother were now being raised by their grandparents because their parents could no longer care for them.

Apparently her father had become physically abusive to her mother. Seeking to escape the pain of black eyes, a battered body, and broken dreams, the mother had left the family home with the two children on at least two previous occasions in what proved to be futile efforts to leave her husband. Invariably, her husband found them and the family reunited, dysfunctional as ever. Finally, it reached the point where the mother knew it was impossible to elude her husband with the two children in tow. She decided to ask her parents to become her children's parents. These grandparents were to take care of their grandchildren until the mother could resume the parenting role, if she could ever again 
assume the role. Apparently the father knew he could not properly care for the children himself, so he did not pursue custody.

This case came to the attention of this researcher, functioning in the role of school psychologist, because the girl's teacher wanted her psychologically evaluated due to the girl's depressed behavior and increasingly deficient academic functioning. After consulting with the teacher on the case and investigating the family history, it became readily apparent that a psychological evaluation was not indicated at that time. This young child was suffering from situational problems due to the loss of the nuclear family, as well as earlier family stress. Additionally, she, along with her brother, were attempting to adjust to her new parents--her grandparents, an adjustment process that was indeed difficult in that both children were having problems functioning in school (Edwards, 1996b).

\section{Definition of Terms}

Multiple designations have been used to label the situation of grandparents raising their grandchildren. The myriad of different nomenclature used include terms such as Grandparents as Parents (GAP), 
Grandparents As Surrogate Parents (GASP), Grandparents As Second

Parents (GASP), Grandparents Offering Love and Devotion (GOLD),

Raising . Our Children's Kids; an Intergenerational Network of

Grandparenting (ROCKING), Grandparents of the Nineties, and

Grandparents As Caregivers (Doucette-Dudman \& LaCure, 1996; Edwards, 1996a; Minkler \& Roe, 1993; Poe, 1992).

This researcher coined the term grandfamilies to easily identify this rapidly growing social phenomenon of grandparents raising grandchildren (Edwards, 1996a \& b). The specific definitions are as follows:

Grandfamily: A family where the grandparent(s), not the child's biological parents, are the primary caregivers in the home. Often one biological parent (usually the mother) may live intermittently in the home; but that parent commonly cedes control of the child to the grandparent(s), usually the grandmother.

Supergrands: Male or female grandparents who are the full-time surrogate parents for their grandchildren in grandfamilies. 
Grandkin: The singular and plural term used to describe children being raised by their grandparents (Edwards, in press).

Encore Parenting: Parenting for a second time by raising one's grandchildren.

The term grandfamilies is an apropos designation that easily allows those unfamiliar with the field of family studies to recall its meaning. There are many single-parent grandfamilies, with only the grandmother or grandfather as chief caregiver. Among some minorities, single, grandmother-headed grandfamilies are pervasive (Edwards, 1996a).

\section{The Formation of Grandfamilies}

Grandkin become wards of their supergrands for a number of reasons. For example, the grandkin's parents may die, their parents may divorce, or their parents may become unemployed and unable to care for their children (Burton, 1992). In addition, when the children of supergrands engage in premarital sex as teenagers, pregnancies happen, resulting in babies. The babies' grandparents must often undertake the role of surrogate parents 
because teenagers usually are unable to assume this responsibility. Teenagers rarely function well in the role of parent, particularly when they do not receive assistance from their sex partners, as is often the case.

Recently, the use of crack cocaine and other illicit drugs has increased among parents. These parents often physically abuse, sexually abuse, or neglect their children. Government social service agencies have responded by removing many of these children from the homes of their parents and have placed them with relatives, frequently with the children's grandparents (Anglin, 1990).

The phenomenon of grandparents raising grandchildren (grandfamilies) is not restricted to the poor of the inner-cities. Grandfamilies are found across the spectrum of society. Grandfamilies can be rich, Native American, White, Asian, and Hispanic. Additionally, grandfamilies are located in almost all urban, suburban, and rural regions of the country. Regardless of the aforementioned, Mildred S. Wood, director of minority affairs for the Washington, D.C.-based National Committee to Preserve Social Security and Medicare, suggested that the low income Black/African-American grandfamily is the most prevalent group 
among all grandfamilies (Brinkley-Rogers, 1997). Thus, Black/African-American grandfamilies are thought to make up the bulk of the grandfamilies in America (Brinkley-Rogers; U.S. Census, 1990).

Some grandkin in this country have led extraordinary lives and have had prestigious, and in some cases, problematic careers, that have made them very well-known. Dignitaries such as President Bill Clinton, Maya Angelou, Carol Burnett, Jack Nicholson, Oprah Winfrey, Newt Gingrich, and Mary Tyler Moore were all raised, at one point, by grandparent(s) (Doucette-Dudman \& LaCure, 1996). However, many grandkin fail miserably in life and end up drug addicted, AIDS infected, incarcerated, and, overall, otherwise negatively affected (Edwards, in press).

Life expectancy is increasing and thus the ranks of grandparents will continue to swell. Usually, grandparents are the only close family members willing to undertake parental responsibility for these unfortunate children, their grandchildren. Grandparents will choose to take in their grandchildren even when they have financial problems. They may feel pressured by moral or religious obligations to prevent their grandchildren's entrance 
into a foster care system they do not view as all that positive (Burton, 1992). Grandparents also choose to care for their grandchildren because the biological relationship of grandparent to grandchild is second only to the parent-child dyad (Kivett, 1991).

\section{Statement of the Problem}

A major problem with the grandfamily phenomenon is that evidence suggests that both grandparents and grandchildren face significant problems with respect to emotional adjustment and the activities of daily living when grandfamilies are formed (Burton, 1992; Minkler \& Roe, 1993). Moreover, and of critical importance for the purposes of this investigation, grandkin may also experience significant academic, behavioral, and emotional schoolrelated problems.

Teachers and other school professionals believe grandkin display more emotional and behavioral problems than children from single- and dual-parent households. Moreover, grandkin are thought to take up excessive amounts of school staff time. However, there are no empirical studies to test the aforementioned 
belief. The noted problems were investigated and empirically tested in this study.

The circumstance of grandparents raising their grandchildren is not exclusively a modern phenomenon. It has been wellchronicled across time that many grandparents have had to shoulder the full responsibility of raising their grandchildren. At the time of the Great Depression in the United States during the 1930s, a significant increase in the number of grandfamilies was evident (Poe, 1992). The trend has continued and is expected to continue into succeeding generations.

Grandfamilies also affect the government and social welfare system of the country. Extensive debates have arisen as to whether grandparents who become surrogate parents to their grandchildren are entitled to receive financial assistance from the government. The Supreme Court case of Miller v. Youakim (1979) ensured that relatives are allowed to receive federal foster care funds under limited conditions. When a child's biological parents are eligible for federal and state aid, and the child is separated from the parents by a court decision, the foster family, comprised of relatives, may receive financial assistance (Berrick, Barth, \& 
Needell, 1994). Nonetheless, nonrelative foster care homes receive more financial assistance than relative foster care homes. This disparate payment system angers some grandparents (Minkler \& Roe, 1993) and adds to the problems that occur when grandparents must raise their grandchildren.

In Florida, like in most states, foster parents who are under contract with the Department of Children and Families receive some type of subsidy. Supergrands do not receive such subsidies unless the children are already eligible for state or federal aid (Barry, 1997). Organizations such as Grandparents As Surrogate Parents and Grandparents As Parents have organized support groups across America to advocate for changes in public policy regarding financial and other social service assistance to grandfamilies.

In poor grandfamilies, the grandkin may fail to do well in school and eventually drop out simply because of a lack of intellectual and educational stimulation. They may turn to juvenile delinquency or other crime. If these children are eventually incarcerated, they require more public resources than if the grandfamily were provided some early social service assistance. 
Certainly poverty is no excuse for criminal behavior; but unequivocally, it is an important risk factor associated with failure in school, dropout behavior, and criminal behavior. Consequently, this new family relationship of grandparents raising grandchildren will have widespread implications for schools as well as the future of society.

\section{The Plight of Encore Parenting}

Raising children can be a difficult proposition. It is almost impossible to be a parent and not have, at least occasionally, problems raising one's children. Even model parents who are financially capable tend to have children who cause them problems. Due to their developing cognitive, emotional, and physical states, all children make mistakes. Similarly, all parents also make mistakes. The confluence and combination of mistakes can lead to conflict and contests of wills in the home despite willing, energetic, and able parents who strive to provide stability, consistency, and nurture.

It is immensely more difficult for grandparents (many over 60 years old) to raise young children. At their stage in life, this 
process of encore parenting, raising children a second time, is doubly difficult. One grandmother, this researcher's mother, provides a typical example of the difficulty that can materialize when raising grandchildren, even on a temporary basis. Generally during the year, this researcher's two young children spend at least two weeks with their grandparents. After the two weeks, their grandparents are often simply exhausted. Grandparents who have to function as full-time surrogate parents frankly face a much more exhausting grandparenting life history.

Another case reflective of the struggle of full-time surrogate parenting involves a grandmother who had assumed responsibility for her grandchildren due to her daughter's drug addiction. The grandmother's statements that follow reflect her disappointment in her drug-dependent child and the difficulties of her new family relationship.

"I need to save myself from all the strain and stress of parenting my grandchildren. At this point in my life, I must make decisions for myself. My grandchildren continue to emotionally abuse me 
because they are angry with their parents for not being with them. I feel I need to make a choice between my health and continuing to raise my grandchildren. I realize that I am the most important person in my grandchildren's life. I love my grandchildren but I feel that I need to find a way to put my grandchildren back with their parents. I'm too old, and I'm tired. Letting go of my grandchildren will be difficult for me" (Poe, 1992, p. 45).

The ambivalence of this grandmother caring for her grandchildren is obviously evident. She knows that her grandchildren desperately need her, but she is unsure if she can adequately take care of their needs. She also is distressed by their mistreatment of her.

This new family relationship of grandparents raising their grandchildren, will not only affect grandparents, but also will certainly have a critical impact on the child(ren). Because many of these children have been abused in some manner, they have trouble functioning appropriately in any environment. Moreover, 
their early life history of problems and negative life events result in these children becoming extremely difficult to raise. When grandkin enter their supergrands' homes, high levels of discord and distress may occur. These grandfamilies frequently exist below the poverty level. As a result, these supergrands, as it is with most supergrands, may not be well-equipped emotionally or financially to function well in the altered family constellation (BrinkleyRogers, 1997).

Black/African-American children are more likely to live with their grandparents than other children, but these grandparents caring for grandchildren may not readily seek assistance from family, friends, and, social service agencies (Brinkley-Rogers, 1997). Older people often consider themselves self-sufficient and will frequently refuse to ask for needed help. In some cases, they have difficulty filling out the paperwork at the schools, much less the paper work required from most social services agencies. Newspaper articles suggest that the situation of Black/AfricanAmerican grandparents (particularly, grandmothers) caring for their grandchildren has reached a point of crisis (Barry, 1997). 
The reality is that any factor that significantly affects the home will tend to generalize to the school. Given the antecedents to grandfamilies, the result is that both supergrands and grandkin likely are pejoratively affected, especially when they also face economic pressures. However, the affect on grandkin has not been empirically tested or reported in any extant published research. In addition, the specific type of affect, negative or otherwise, on students and their school functioning has not been examined. Thus, this study was conducted to determine whether grandchildren who live with their grandparents are negatively affected relative to the former's functioning within the school setting. Given data that suggest Black/African-American families comprise most of the grandfamilies in the country, the study utilized a low-income, Black/African-American participant sample.

\section{Purpose of the Study}

The present study is grounded in the conceptual framework of attachment and social support theory. The breakdown of the 
nuclear family that elicits the phenomenon of grandfamilies often leads to children developing insecure vertical and horizontal attachment. Attachment difficulty in childhood is related to poor psychological adjustment across the life span, as well as problems with daily living activities such as school functioning. A relevant maxim is often quoted: "as the twig is bent, so grows the tree."

When grandfamilies must be created, the grandkin's previously established social support networks are frequently shattered. The supergrands also tend to lose contact with their social network because they must spend much of their time with their grandkin. In due course, they often end up traveling in different social circles than their friends. Social support via social networks has been shown to serve as a buffer to stress and stress symptomatology (Antonucci, 1990; Hoffman, Ushpiz, \& Levy-Shiff, 1988; Levitt, Guacci-Franco, \& Levitt, 1994). With splintered social networks, supergrands tend to experience stress that results in heightened illness, depression, anxiety, alcoholism, and increased smoking (Burton, 1992). Will grandkin, like their supergrands, tend to display greater levels and intensity of stress? 
The hypotheses are that grandkin will evidence higher

Internalizing, Externalizing, and clinically significant Total Behavior Problems T-scores on the Achenbach Teacher Report Form (Achenbach, 1991) when compared with similar peers. In addition, grandkin will be referred significantly more to the schools' administration and guidance departments for discipline problems than their peers. The overall purpose of this study, therefore, is to determine the emotional and behavioral school functioning of students who live in grandfamilies.

\section{Statement of Hypotheses}

1. There will be no significant difference between students from low income grandfamilies and a comparison group of students from low income single- and dual-parent households, using the Teacher Report Form Internalizing Factor and Externalizing Factor.

2. Students from low income grandfamilies will be rated equal to a comparison group of students from low income single- and dualparent households on the Internalizing Factor of the Teacher Report Form. 
3. Students from low income grandfamilies will be rated equal to a comparison group of students from low income single- and dualparent households on the Externalizing Factor of the Teacher Report Form.

4. Students from low income grandfamilies and a comparison group of students from low income single- and dual-parent households will receive an equal number of clinically significant scores on the Total Behavior Problem Factor of the Teacher Report Form.

5. Students from low income grandfamilies and a comparison group of students from low income single- and dual-parent households will receive an equal number of discipline referrals to their schools' guidance or administration departments.

\section{Limitations of the Study}

The following limitations are associated with this research study. First, only 54 grandkin and 54 children from eight elementary schools, totaling 108 children participated in the study. The response rate for grandkin was 53 percent and the response rate for the children from single- and dual-parents households was 
56 percent. These rates are considered adequate for the low income population utilized, but not ideal. It may that the grandfamilies who participated in the study were different from the grandfamilies who did not wish to participate in the study. Random selection and the use of a comparison group may have reduced some of the problems associated with the response rate in this study.

An additional limitation involved the utilization of a matched-group sample. Clearly, when using matching one cannot match every single variable. It is impossible to exactly duplicate the experiences of the grandkin within the children living in singleand dual-parent households. For example, many grandkin experience childhood trauma or negative life events. The comparison group was not matched on this variable. To a degree, matching problems were controlled for by using a nationally normed and standardized measure of emotional and behavioral problems. It may also be that the greater difficulties experienced by grandkin as identified in this study relates more to prior trauma than to their pattern of upbringing. 


\section{Organization of the Remaining Chapters}

Chapter II provides a review and synthesis of literature on the grandfamily phenomenon and the theoretical bases for the study. Chapter III details the research design and methodology utilized to collect and analyze the data. Chapter IV presents the findings and analyzes the data. Chapter $\mathrm{V}$ provides a brief summary of the study and contains conclusions and recommendations. This chapter also describes an intervention project designed to assist grandfamilies. Chapter VI presents a case study of a fourth-grade student and his grandfamily. 


\section{CHAPTER II}

\section{REVIEW OF THE LITERATURE}

\section{Introduction}

The purpose of the chapter is to provide a review of the literature as it relates to grandfamilies. In addition, it addresses the stakeholders' influence on the school functioning of grandchildren. The chapter begins with a discussion of the demographic makeup of grandfamilies. Issues relative to the experiences encountered by parents, grandparents, and grandchildren are presented. Next, the impact of grandfamilies on schools is described. Finally, the theoretical bases for the problems experienced by grandfamilies are addressed. The theoretical framework provides a priori support for why grandkin may have problems functioning in school.

\section{Demographics}

Grandparents raising their grandchildren on a full-time basis is a growing social phenomenon. In the United States, this type of family unit in has expanded by approximately 40 percent in the 
past decade (Strom \& Strom, 1993). Across the nation, more than

3.2 million grandchildren under the age of 18 live with their

grandparents (U.S. Census, 1990). In certain grandfamilies, the child(ren)'s mothers also live in the home.

The United States Bureau of the Census reports that of their estimate of 3.2 million grandkin, about 39 percent are from Black/African-American households; around 25 percent from White households; and approximately 23 percent from Hispanic households (U.S. Census, 1990). However, there are some who take issue with the Census data. They believe that there are many more Black/African-American grandfamilies than currently identified by the survey. Mildred S. Wood, referred to in Chapter I, noted from her Committee data, that Black/African-American children are four times as likely to live with their grandparents as White children and twice as likely as Hispanic children (Brinkley-Rogers, 1997). 
Figure 1 through 7 shows the U.S. Census (1990) data on grandkin. Both Local and national data are included.

Figure 1 shows the racial breakdown of the percentages of children in the United States under the age of 18 who live with their grandparents.

Figure 1: Ethnic Data on Grandfamilies

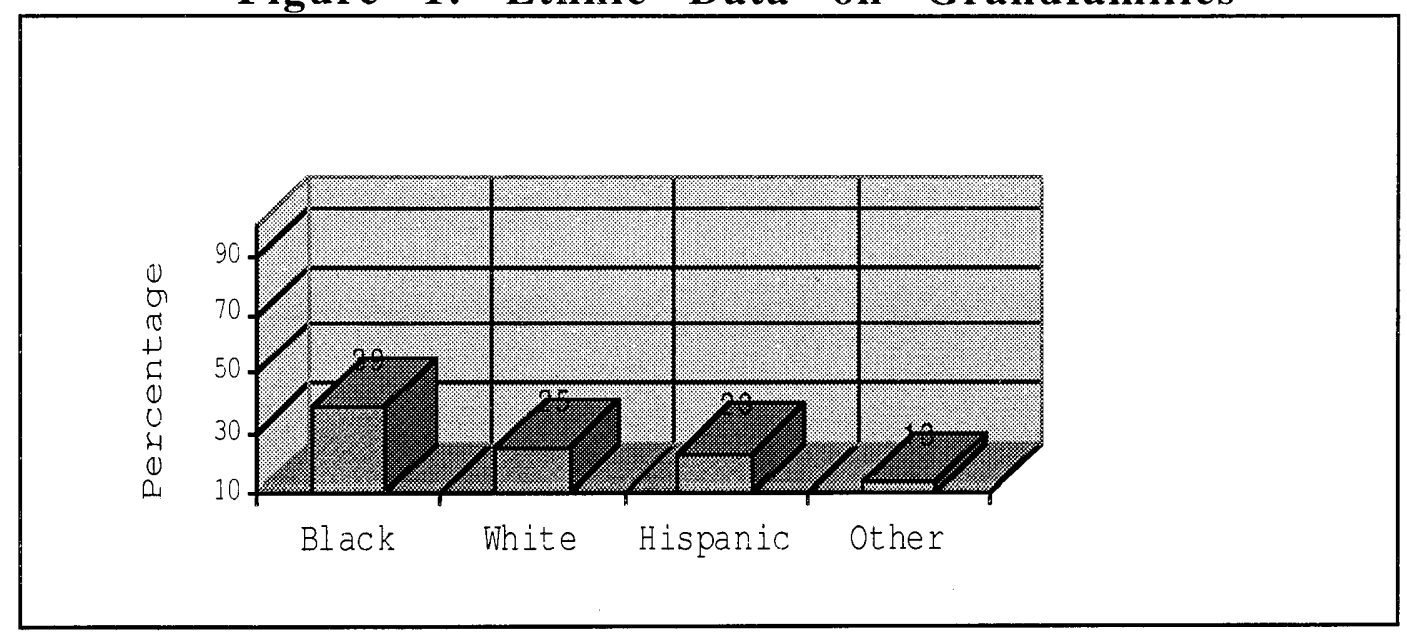

Figure 1

In Broward County, Florida, where this study was conducted, approximately 4,500 supergrands were raising about 5,800 grandkin. Nearly half of the children were under the age of ten. Roughly seven percent of the households had two or more children. 
Figure 2 provides data on the approximate number of supergrands and grandkin living in Broward County, Florida.

Figure 2: Supergrands and Grandkin in Broward

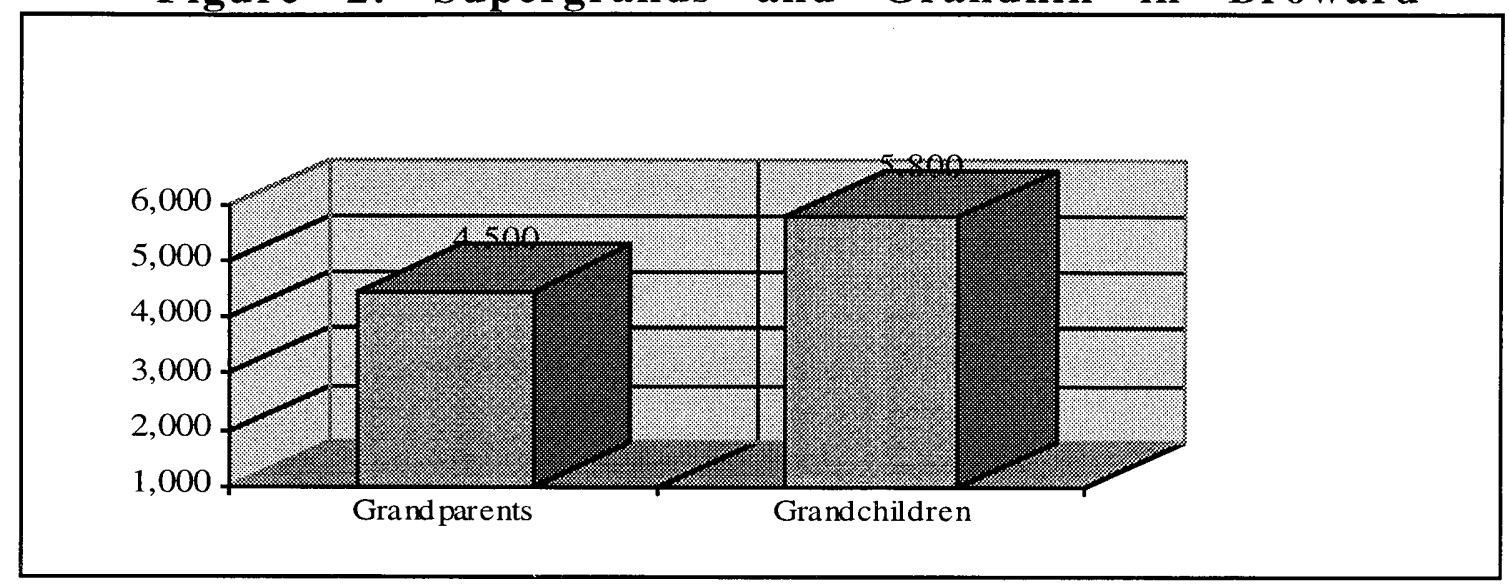

Figure 2

Figure 3 presents approximate percentages of grandkin under

10 years of age and 10-year-olds and older in Broward County, Florida, who live with supergrands.

Figure 3: Ages of Grandkin Living in Broward

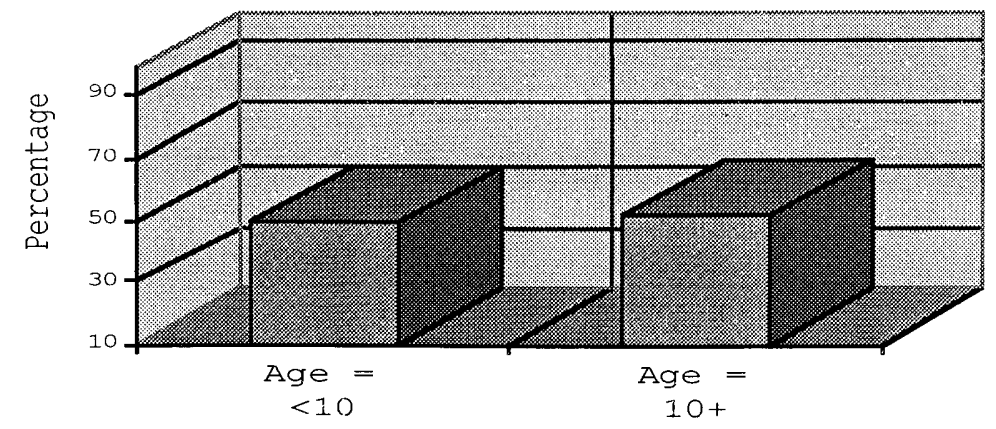

Figure 3 
Figure 4 includes approximate percentages of one grandkin or two or more grandkin grandfamilies in Broward County, Florida.

Figure 4: Grandkin Per Grandfamily in Broward

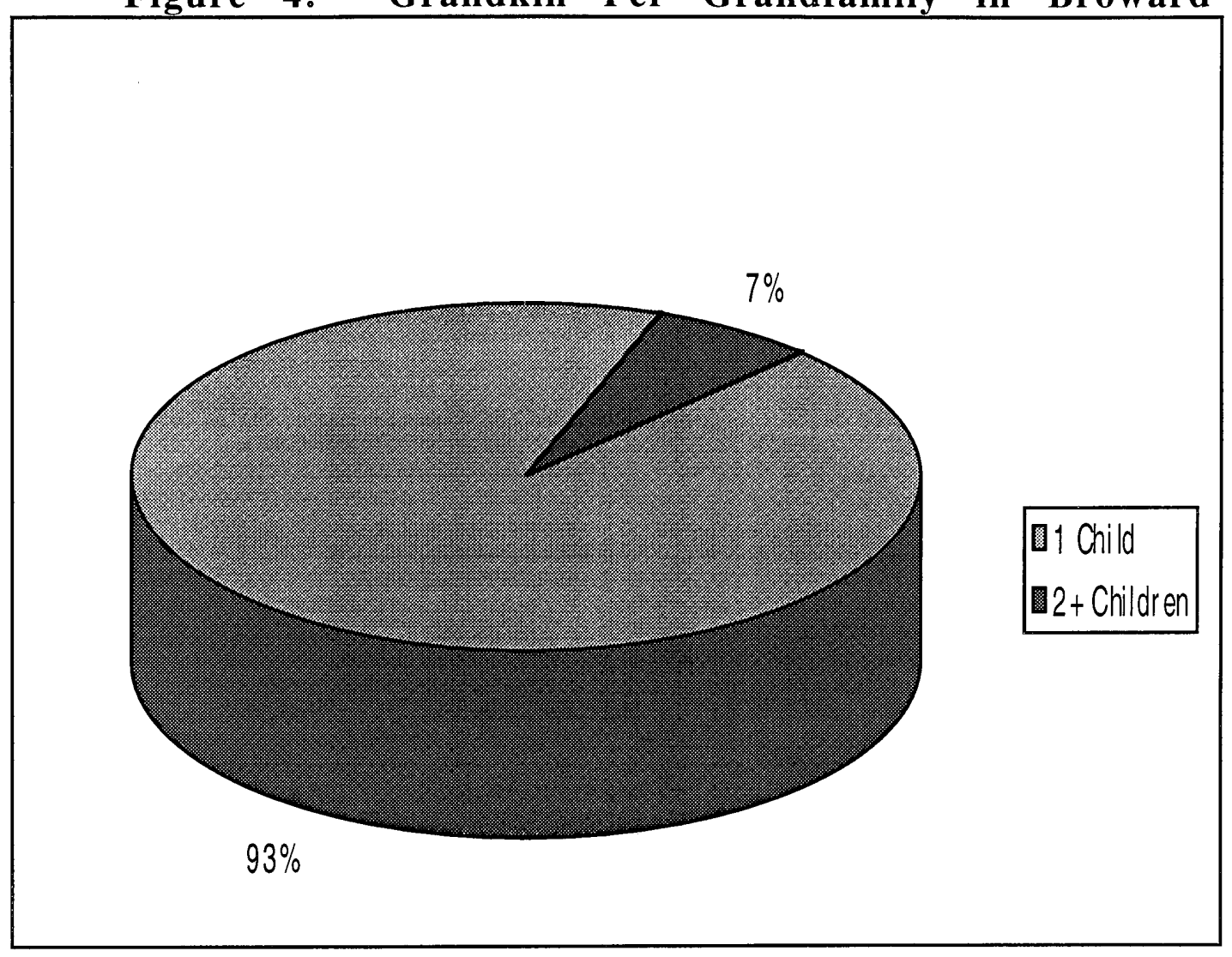

Figure 4

More than half of the supergrands heading these households did not have a high school diploma. Only one percent of supergrands had a four-year college degree. This lack of education severely limits the ability of grandparents' to help their children with school work and homework. 
Figure 5 shows the educational degree status in approximate percentages of supergrands in Broward County, Florida.

\section{Figure 5: Supergrands' Educational Degree Status}

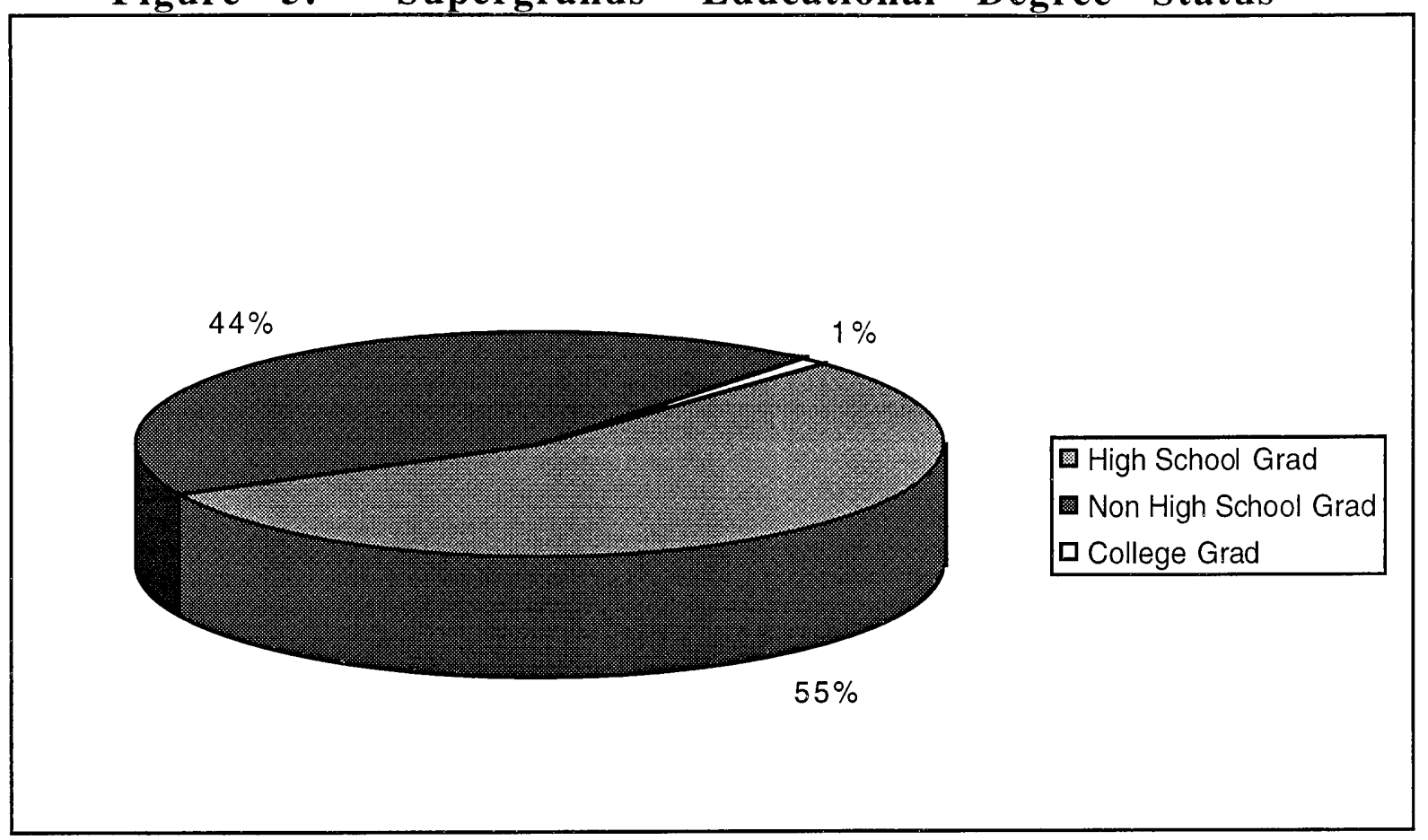

Figure 5

Most of the grandfamilies in the county were poor or somewhat poor. Two-thirds earned less than the 1990 median Broward household income of about $\$ 30,000$. A third of the households had an income of less than $\$ 10,000$. Barely one in four of the households had incomes above $\$ 40,000$. 
Over half of the grandparents raising grandchildren were women without husbands in the home. Another 10 percent were men without wives in the home. The remaining 40 percent had both a husband and wife in the home (U.S. Census, 1990).

Figure 6 presents the income levels for grandfamilies in Broward, County, Florida, in approximate percentages.

Figure 6: Grandfamily Income in Broward

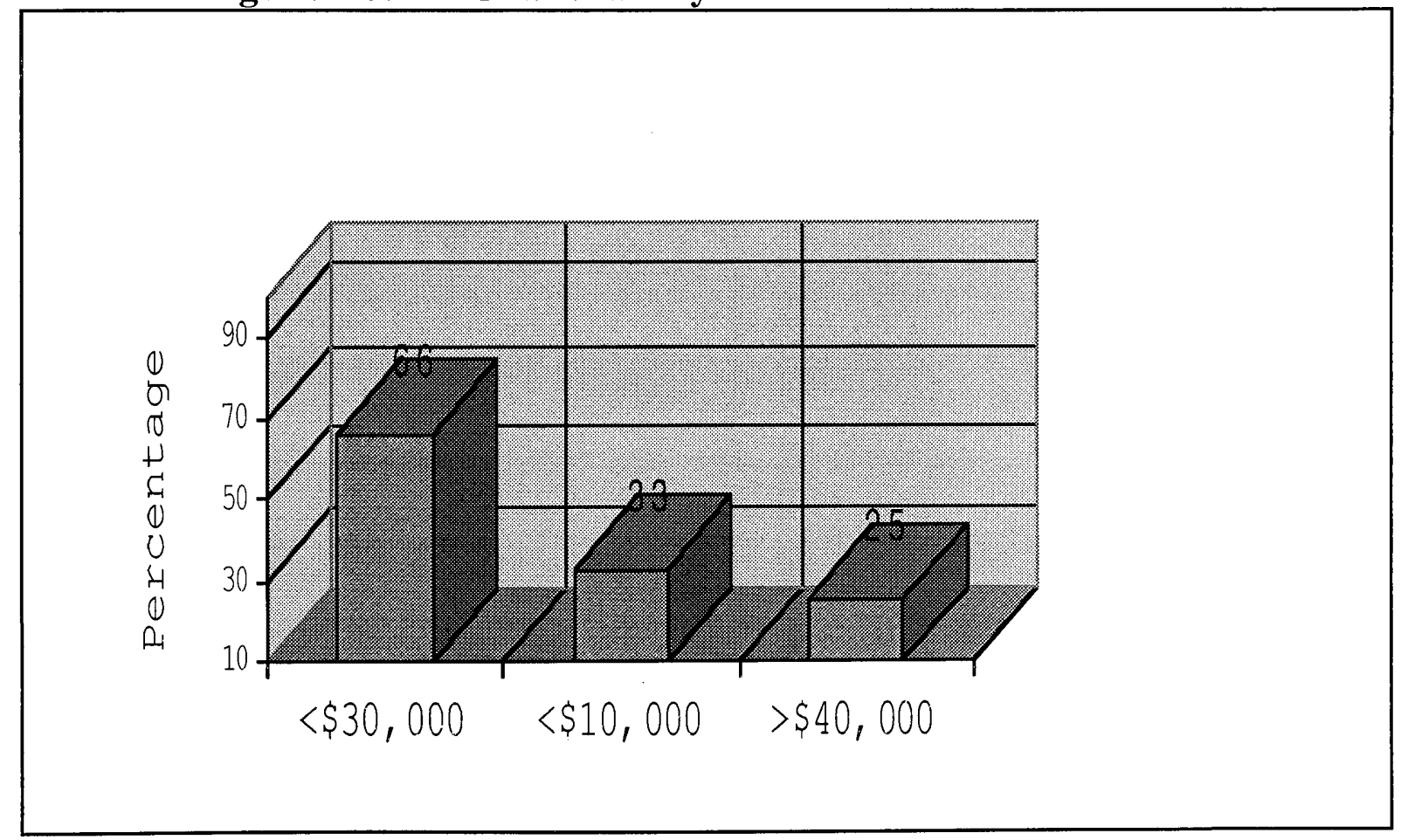

Figure 6 
Figure 7 describes the composition of the heads of households for grandfamilies in Broward County, Florida, in approximate percentages.

\section{Figure 7: Composition of Grandfamilies As Heads of Household in Broward}

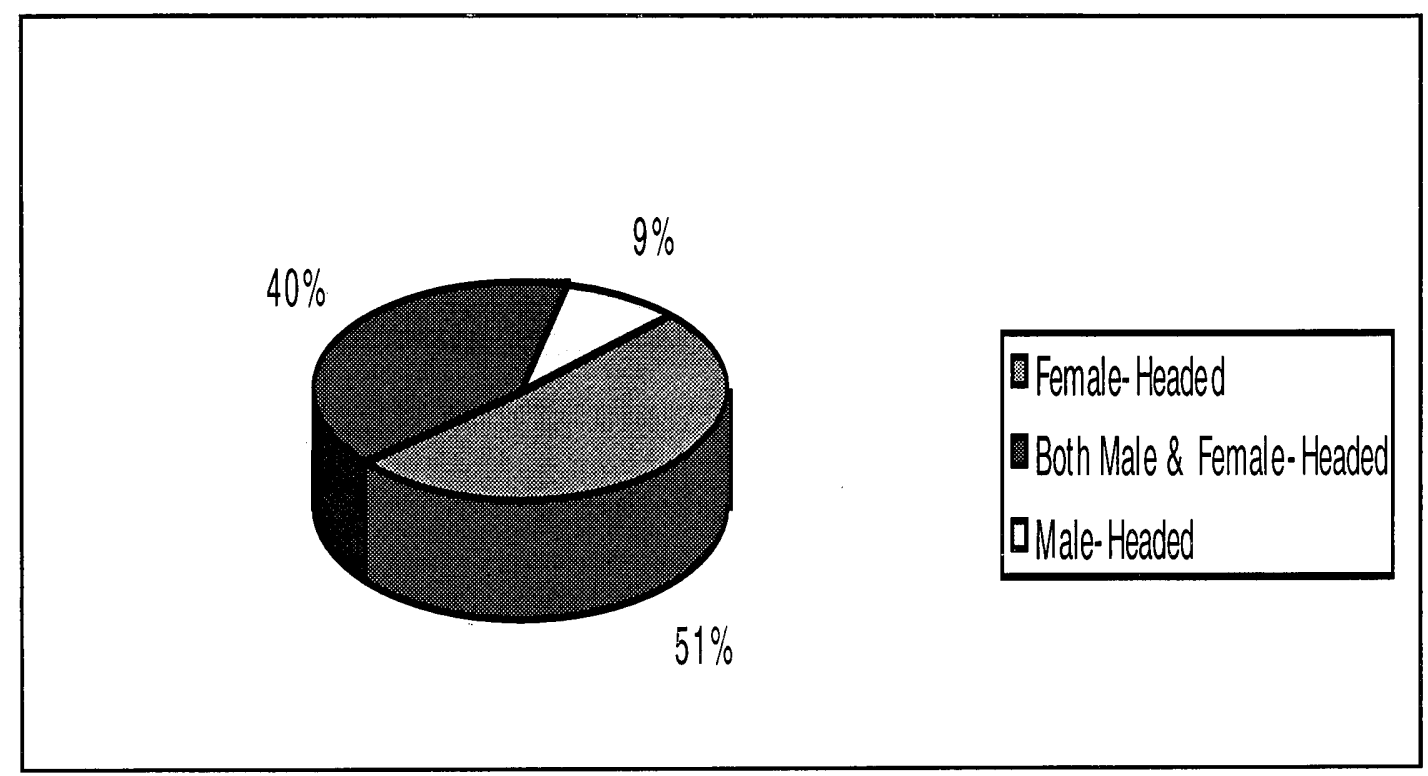

Figure 7

The Grandparent Role

Grandparenthood has been historically viewed as a role without any definitive characteristics because there are no explicitly prescribed functions (Troll, 1983). Grandparents may or may not be expected to help with the socialization of their grandchildren. They may choose from among a wealth of roles 
they can fill in their grandchildren's lives, including serving as allies, disciplinarians, teachers, and friends. There are so many grandparenting styles that although role norms may be present, they are less robust and persistent when compared with other family norms (Johnson, 1983).

During the 1980 s several researchers suggest that in American society it has been difficult to socialize older adults to the grandparent role (Johnson, 1983; Kornhaber, 1985). This difficulty is thought to be a result of American's emphasis on individualism and narcissism and a certain lack of commitment to grandchildren (Kornhaber, 1985).

Grandparents may believe there is some lack of respect for the elderly, and they may concomitantly circumscribe their roles because they wish to mitigate any feelings of rejection from their children or grandchildren. However, there is some satisfaction noted with respect to the grandparenting role (Thomas, 1986). This satisfaction is usually seen as a function of the supportive or interactive dimensions (Fischer, 1983). That is, grandparents may be valued for their financial support, backup, watch dog, safety valve, and stabilizing functions (Johnson, 1983; Troll, 1983). 
The preponderance of research suggests that often

grandparents believe they do not have the right to influence the socialization of their grandchildren when the children's parents are available to fill this role. This norm of noninterference (Cherlin \& Furstenberg, 1986), suggests that generally American grandparents neither want, nor are expected, to take an active role in the parenting of their minor grandchildren. With the emergence of the grandfamily, critical role conflicts arise. The noted conflict ordinarily involves, on the one hand, the grandparents' desire to enter their "golden years" when relaxation, independence, and enjoying life with friends is of principal interest. On the other hand, grandparents realize their family obligations and the needs of their grandchildren may take precedence over their own needs. When the surrogate parenting role is forced on grandparents for any reason, it may affect their emotional well-being. When the emotional well-being of supergrands is negatively affected, it may result in the grandparents having less energy to devote to the rearing of their grandchildren.

The ages of grandparents and grandchildren are two important factors that affect the relationship and connections 
between the two. Generally, grandparents become less actively involved as both grandparents and grandchildren age (Johnson, 1983; Thomas, 1986). Grandparents are most involved during their grandchild's birth to teenage years (Cherlin \& Furstenberg, 1986). As the ages of grandparents increase with the gradual graying of the country's population, many older grandparents will take on the surrogate parenting of their minor grandchildren. This new role becomes more difficult for older surrogate grandparents.

\section{Gender Issues and Grandparents}

Much of the literature reveals the relative importance of female roles over male roles among grandparents. Kivett (1991) reported a tendency for grandchildren to become more involved with maternal, than paternal, grandparents. Cherlin and Furstenberg (1986) also noted that grandfathers provide more tangible and material help than grandmothers, but the latter give more emotional and expressive assistance. In addition, research findings indicate that the gender of the grandchild meant more to grandfathers than to grandmothers. The communication and relationship between grandsons and grandfathers tend to be more 
frequent and perceptible in nature than communication with granddaughters (Cherlin \& Furstenberg, 1986). The aforementioned notwithstanding, maternal grandmothers, regardless of socioeconomic status, have been reported to give more assistance, than other grandparents, to both granddaughters and grandsons (Kivett, 1991). Thus, one understands why many grandfamilies are comprised of maternal grandmothers raising their grandkin.

\section{Cultural Factors}

There are extensive differences among disparate cultures in the relationship between grandparents and their grandchildren. Grandparents who take on the surrogate parental role are more often seen in ethnic families, such as Blacks and Hispanics (Burton, 1992; Cherlin \& Furstenberg, 1986; Lubben \& Becerra, 1987). These ethnic family networks are less likely to succumb to norms of noninterference, particularly in single parent households (Kornhaber \& Woodward, 1981). Traditionally, there is much reciprocation of goods, services, and emotional support in ethnic families where grandparents live with adult children (Cherlin \& 
Furstenberg, 1986). However, there is greater unidirectional aid and less reciprocity when the family networks are composed of grandparents and minor grandchildren only (Burton, 1992). In a recent study of the family networks of both inner-city Blacks and Whites, it was found that the support provided to the elderly by proximal relatives was tenuous, possibly due to the many distractions or competing commitments these relatives encounter (Johnson \& Barer, 1990). When Black grandparents take on a surrogate parenting role, they were found to experience stress that resulted in heightened illness, depression, anxiety, alcoholism, and increased smoking (Burton, 1992).

\section{Adjustment Issues and Grandparents}

The reasons for the phenomenon of grandfamilies significantly influence the adjustment of both children and grandparents in these families. In cases where the grandchildren's biological parents die, there tends to be an easier adjustment process for all involved. The grandparents need not concern themselves about the grandchildren being removed by social services or that the children's biological parents will reappear to 
interfere with the parenting process. Once the grieving process has been completed, the grandfamily realizes that nothing anyone could have done would have changed the outcome and they are now a grandfamily forever. In cases such as parental death, more support from family and friends and, perhaps, insurance money, is made available to the grandfamily (Poe, 1992).

When grandfamilies emerge due to parental drug addiction, divorce, teenage premarital childbearing, and other such events, emotional and instrumental support from family and friends are frequently very scarce (Burton, 1992). The grandchildren in these situations tend to suffer from problems such as Attention Deficit Hyperactive Disorder, Conduct or Behavior Disorder, learning problems, fetal alcohol syndrome, and the like (Doucette-Dudman \& LaCure, 1996; Dubowitz \& Sawyer 1994; Sawyer \& Dubowitz 1994). Children with these problems cause grandparents to have to develop highly effective parenting skills if they wish their grandchildren to succeed at home, in school, and at life.

Grandparents who have not spent much contemporaneous time with children also need to relearn how to exist with small children in the home. 
In the above noted cases, when a biological parent resides in the home, whether or not on a permanent basis, they often provide little in the way of financial assistance to the grandfamily (Burton, 1992). Frequently, it is the grandparents who must provide the financial support not only to their grandchildren but also to their children, their grandchildren's parents. Even when state agencies are involved in the removal of children from the homes of their parents, once the grandparents become legal guardians, they tend to receive, little, if any, social service assistance (Poe, 1992;

Minkler, \& Roe; 1993). This situation does not ease, but may exacerbate, the problems experienced by grandfamilies.

Grandparents must also frequently modify their living arrangement to accommodate their grandchildren. Grandparents who may have sold the family home upon retirement to move to small apartments and condos may need greater space for their grandchildren. Living in cramped quarters can lead to a great deal of ancillary stress. Conversely, having to move can negatively impact the elderly, given the importance of neighborhood-based social relations (Brown \& Harris, 1978). Generally, the familiar neighborhood environment is the place where the grandparents 
have previously established a support network to help buffer any impending stress.

\section{Grandparents' Experience}

Grandparents who raise their grandchildren may experience several emotions as a result of their new role. These emotions include concern, fear, anger, depression, acceptance, and, finally, either resignation or happiness. Grandparents tend to vacillate from one emotion to another until they can accept their new role and enter the state of happiness or resignation (Edwards, 1996a, Minkler \& Roe, 1993; Poe, 1992).

Grandparents express concern for their children and grandchildren when they first learn of the difficulties that led to the grandparents' surrogate parenting. They also feel a degree of fear about their ability to adequately fill the role of parent. Anger frequently occurs, directed toward their children and grandchildren because both groups of children are forcing the role of parents unto the grandparents for a second time. If grandparents have significant difficulty filling this role, they may become depressed and resort to drinking, smoking, or they may 
actually become physically ill (Burton, 1992; Poe, 1992). After some time, most grandparents accept their new role and enjoy the opportunity of encore parenting, although it remains a difficult process (Minkler \& Roe, 1993). However, some grandparents, rather than happily function as surrogate parents, become resigned to the role and function poorly as parents to the extent that their grandchildren may have to be removed from the home (Poe, 1992). Additionally, some grandparents may even renounce the role and give up their grandchildren to another family member or to the foster care system (Magruder, 1994; Strom \& Strom 1993).

\section{Grandchildren's Experience}

Children who are removed from their nuclear families and enter grandfamilies may experience a bevy of emotions, including neglect, loss, rejection, anger, fear, acceptance, and, finally, either love or repudiation (Edwards, in press). These children generally experience a history of acute and extensive hardship in the areas of cognitive, personality, and social functioning (Dubowitz \& Sawyer, 1994; Sawyer \& Dubowitz, 1994). 
Initially, due to problems in the nuclear family, the children may feel neglected because the attention of their parents may be diverted away from the children. When their parents no longer can care for them and they are sent to live with grandparents, feelings of loss, and perhaps, rejection, may ensue (Poe, 1992;

Minkler \& Roe, 1993; Doucette-Dudman \& LaCure 1996).

There is a tendency for children to fear they will never see their parents again as noted in the initial illustration. The sequence of emotions often continues into anger, directed at their parents for leaving them and at their grandparents for trying to take their parents' place. The grandkin often realize the sacrifice their grandparents make for them. Regardless, there is a degree of ambivalence, and the grandkin tend to have difficulty coping with the debilitating cycle of emotions (Poe, 1992; Minkler \& Roe, 1993; Doucette-Dudman \& LaCure, 1996).

Once these grandkin learn to accept that they have become permanent members of grandfamilies, they either develop strong feelings of love, or repudiation, for their supergrands. The former feelings bind them to their grandparents, whom they try not to disappoint. The latter, however, may drive them away from their 
grandparents (Poe, 1992; Minkler \& Roe, 1993; Doucette-Dudman \& LaCure 1996). Regardless of which of these two emotions is most prevalent with grandkin, there tends to be conflict in the home. Unless both grandparents and grandkin learn methods of coping with the stressors and the array of fluctuating emotions, grandkin again may fail to function adequately at home and at school.

It appears grandkin also struggle in life because they tend to have difficulty developing positive, nurturing relationships with others for fear of being rejected once again (Edwards, in press). When working with these grandkin in schools, one commonly finds they often alternate between articulating feelings of love and displeasure toward their grandparents (Edwards, 1996a). They appreciate their grandparents for the role they have taken as surrogate parents in their lives. Yet, they harbor some resentment towards their grandparents due to the necessary disciplinary element of the grandparents' role as surrogate parents (1996b).

When the natural parents are intermittently involved with the family, there is a blurring of the lines of authority. The parents may oppose or diminish the parental authority of the grandparents (Poe, 1992). The grandchildren also do not know how long they 
will have access to their parents and may become anxious and confused as to whom they should respond to as parent (DoucetteDudman \& LaCure 1996). This adds to the grandchildren's problems developing appropriate interpersonal relationships. With a lack of continuity within the nuclear family, children have a difficult time establishing a strong ego and a positive self-concept.

In these grandfamilies, then, no matter how the grandchildren behave, they will affect the emotional well-being of their grandparents, for better or more likely, for worse, simply because they exist (Kornhaber \& Woodward, 1981). Similarly, grandparents will affect the emotional well-being and educational functioning of their grandchildren, when the former serve as caregivers.

\section{Developmental Issues and Children}

Many studies indicate that the ability of children to appropriately function in the social world comes about as a product of close relationships experienced early in life (Hartup, 1989). Two types of relationships particularly impact the development of children. Before they begin to walk, most children start forming 
vertical attachments. These attachments are with people who are more knowledgeable and socially astute than the child. Usually, these relationships involve children and adults where synchronous exchanges are relevant (Hartup, 1989; Edwards, in press).

Additionally, children need to form close relationships that are horizontal. The horizontal relationships are usually with peers where their social judgment and understanding are comparable. Most often, these relationships are formed with individuals of similar ages and consist of reciprocal interchanges (see Hartup, 1989). The relationships that children form early in life serve as the basis for their later development with respect to cognitive, social, and emotional functioning.

The underlying foundation for social skills proficiency proceeds from these first vertical attachment relationships and the satisfaction of needs. On the other hand, horizontal relationships form the attendant condition whereby children strengthen these skills with similarly developing peers. Early horizontal attachment relationships foster the skills of cooperation, competition, and intimacy necessary for the ability to succeed in social relations (see Hartup, 1989). 
Vertical and horizontal relationships are differentially related to the individual child's development across the life span. Vertical relationships allow children to successfully realize one of the most basic goals (i.e., safety/protection) of Maslow's (1943) hierarchy of needs during their early life history of greatest dependency. Maslow's theory suggests that most children in American society desire a safe, orderly, predictable, and organized environment. Children prefer parents who effectively guard them from harm. Most children have almost an innate aversion to an unmanageable, hazardous, and unreliable world. For example, capricious or unfair parents tend to make children feel unsafe and anxious. Separation, spousal abuse, divorce, or death within a family often lead to panic in children (Maslow, 1943).

When children are the beneficiaries of loving and consistent parenting, they, more often than not, form secure attachment relationships with their parents as these children develop across the life span. In addition, they are readily willing to investigate their environment without fear of being hurt. Children who are deprived of love and care during infancy often develop insecure attachment relationships. This is the case with many grandkin. 
From inadequate care, children and grandkin learn to be extremely cautious and somewhat apprehensive about their environment and their place therein (Toth \& Cicchetti, 1996a).

Research supports the belief that children who have been the beneficiaries of secure relationships in early childhood tend to have more friends among their nursery school classmates than children who have not been able to establish secure relationships. The securely attached nursery school children are much more interested in social contact and are better able to provide appropriate advice and support to their classmates (Sroufe \& Fleeson, 1986).

In the classroom setting, the interaction between the securely and insecurely attached students and their teachers also shows clear differences. Relative to their need for emotional support, insecurely attached children seek out their teachers at a higher frequency than their securely attached classmates (Sroufe \& Fleeson, 1986). These children often attempt to garner attention, whether it is positive or negative. Many times, because of their behavioral difficulty, all the attention they receive is a function of negative consequences. Teachers indicate that with these children 
they are constantly designing and modifying interventions to help them perform better in class.

Additional studies have shown that the security children experience in the interaction between their mothers is correlated with the children's functioning in the school setting (Toth \& Cicchetti, 1996b). Furthermore, the data suggest that relationships with others appear to be important precursors of feelings toward oneself (Hartup, 1989). The available evidence indicates that the quality of a six-year-old child's attachment relationship to that child's mother is strongly related to the child's self-esteem. Moreover, this relationship is related to the child's opinion about his or her own cognitive ability and popularity (Cassidy, 1988). One can be confident in stating that having friends increases children's chances of proper social emotional development. For most students who establish and maintain socially appropriate friendships, it is likely they had secure attachment experiences early in life.

Grandkin whose early life history often involve periods of neglect, rejection, and inconsistency will tend to develop insecure attachments. These grandkin are not able to securely attach to 
their parents. In fact, if they become securely attached to their parents and are abruptly removed from them, there is potential for depression to arise (Maslow, 1943). As a result, grandkin tend to experience all the aforementioned problems associated with insecure attachments.

\section{Perspective of School Professionals}

Dealing with disruptive children is becoming a predominant problem in elementary school public and private education. School professionals are facing burnout or emotional exhaustion simply from having to deal with behavioral problems on a daily basis (Gold \& Roth, 1993; Montalvo, Bair, \& Boor, 1995). The general public views lack of discipline as one of the major problems facing schools (Elam \& Rose, 1995).

Everyday, elementary school professionals, such as principals, assistant principals, and guidance counselors, have to deal with students who are referred to them due to discipline problems. Assistant principals and guidance counselors bear the brunt of this excessive student contact. 
Students are referred for a myriad of in-class and in-school problems. For example, students may be referred to assistant principals because they have temper tantrums, refuse to follow school and class rules, become defiant, and behave in either a verbally or physically aggressive manner. Students can be referred to guidance counselors due to impulsivity, distractibility, anxiety, poor self-concepts, and overall worry. Children in foster care may be prone to demonstrate the aforementioned problems. Anecdotal data from teachers also suggest that grandkin demonstrate similar behavioral problems (Edwards, 1996b). Assistant principals believe that the role they fill as disciplinarians for these children often limits their time to utilize their skills among all students throughout the whole school (Buckner \& Jones, 1990; Gorton, 1987). Yet, supervising student behavior in school buildings and grounds and dealing with student discipline problems continue to be the number one rated actual role of assistant principals (Calabrese, 1991; Pellicer \& Stevenson, 1991; Smith, 1987).

Teachers and principals also see the assistant principal's role as that of disciplinarian (Calabrese \& Tucker-Ladd, 1991). 
Assistant principals want to be involved in areas of public relations, advising parent groups, curriculum, and instruction (Gorton, 1987). They wish to play a more integral part in establishing the overall direction of the school. They aspired to their positions because they wish to make a positive impact in the lives of young people, yet they are primarily relegated to the role of the "bad guy." These highly credentialed, educational professionals feel almost belittled in this role of disciplinarian within the schools (Calabrese, 1991; Scoggins \& Bishop, 1993).

Given their excellent training and skills, assistant principals should be able to develop proactive, rather than reactive, orientations when working with students who have behavioral problems. They need to spend more time working with parents (supergrands), students (grandkin), and teachers in primary prevention to attenuate the intensity of behavioral problems. The outcome could decrease the need for excessive disciplinary referrals in the schools (Hunter, 1990).

When assistant principals find the etiology of the problem, they will be better able to solve it before it can escalate to unmanageable proportions. Seemingly, with respect to grandkin, 
the antecedents of disruptive behavior are within the dysfunctional family systems that lead to insecure attachments and insufficient social support.

Guidance counselors must also respond to the requests of teachers to help students with behavioral and emotional problems. Guidance counselors are inundated with requests to provide individual counseling to children who are having either behavioral or emotional concerns as a consequence of family problems. In fact, individual counseling is considered the number one actual role filled by elementary school guidance counselors (Hardesty \& Dillard, 1994; Howard, 1989; Morse \& Russell, 1988;). Of course, long-standing socially maladjusted behavior is very difficult to change.

When a child begins the counseling process after socially maladjusted behavior is already firmly established, counseling can rarely ameliorate such behavior (Harrington, Fudge, Rutter, Pickles, \& Hill, 1991). Guidance counselors are feeling some pressure from teachers and researchers in their field to also develop a more proactive focus to solving students' behavioral and emotional problems. 
For example, the Commission on Precollege Guidance and Counseling (1986) noted that "the challenge for elementary schools is to find new ways to reach out to parents and enlist their assistance in the educational process, while also providing more support services for the children who cannot count on support at home" (p. 6). Indeed, this statement strongly addresses the needs of grandfamilies. As was mentioned, grandkin encounter a great deal of difficulty in school. In addition, their grandparents are frequently unable to provide the support these children desperately need to function well in the school setting.

Researchers and policymakers in the field of elementary school guidance counseling are lobbying for counselors to spend more time working in parent education and training because it is an extremely valuable tool to prevent and ameliorate behavior problems (Wilgus \& Shelley, 1988). The emergent family structures of grandfamilies particularly require elementary school guidance counselors to develop programs to educate grandparents as to the workings of the school, teach behavior management skills, refer to external agencies, and provide educational and emotional support to both grandkin and supergrands. 


\section{Children in Foster care}

There is a paucity of research about children living in grandfamilies. Most of the studies conducted with children living away from their biological parents have involved nonrelative foster home placements and placements with relatives, labeled kinship placements. There are also some references in the literature that provide data on children living in orphanages in foreign countries. Most state family agencies prefer to place children who must live away from their biological parents with members of their biological family and try to avoid nonrelative foster placement (Magruder, 1994).

The strong push for kinship placements for children in need of foster care services is due to several factors. The country has entered an era where the importance of the family is almost nonpareil. There is a general belief that the extended family provides these children with a connection to their family history. In addition, when these children live with relatives, they are expected to receive a level of stability and feelings of belonging that no nonrelative family placement could possibly provide. 
There are other reasons why placements with nonrelatives are looked upon somewhat askance. Children who live with nonrelatives enter a new environment where they must adjust and adapt to complete strangers. When children in foster care live with kin, there is a much greater opportunity for the children to interact with their biological parents (Berrick et al., 1994).

There are those in the social services field who suggest that placement with a relative is not the best practice when that child is removed from the parental home due to some type of abuse (Doucette-Dudman \& LaCure, 1996; Dubowitz, Feigelman, Harrington, Starr, Zuravin, and Sawyer, 1994). The thought is that if one member of the family network is considered unsuitable to raise the child, the complete family network may be dysfunctional. Moreover, even when the family network is not dysfunctional, it is inappropriate to place children within the network when an inimical biological parent will have contact with the child. Finally, given the limited screenings, monitoring, and support provided to kinship foster care placements, the child is actually benefited by placement outside the family network (Berrick et al., 1994). 
The opinions on this issue of relative and nonrelative foster care placements are indeed divergent. Yet, there is one constant, both children in relative and nonrelative foster care placements face a myriad of problems. It was recently reported that both groups of children have physical, developmental, mental health, and school problems. Specifically, these problems include much higher rates of asthma, anemia, vision, dental problems, and developmental delays. They also experience cognitive and academic delays (Dubowitz et al., 1994).

Children who are removed from their biological parents because of negative life events may show a proclivity to model the dysfunctional interpersonal interactions and family patterns that led to their removal (Colon, 1978). Colon reported that the nuclear family is a fundamental component to the children's process of achieving integration in their lives.

Harlow (1959), in his seminal study using monkeys, found that baby monkeys failed to develop properly when they were fed and allowed to associate with a wire replicate of their mothers. When fed with a wire replicate covered by a soft terry cloth, these monkeys experienced fewer problems. Of course, when fed by 
their biological mothers the monkeys experienced the least developmental problems. Moreover, when young monkeys are separated from their mothers subsequent to forming attachments, they show signs of depression (Harlow \& Suomi, 1971).

In human infants there is some evidence to suggest that prolonged separation of the infant from the child's mother can lead to symptoms of depression (Hetherington, Stouwie, \& Ridberg, 1971). More recent studies of children living in orphanages and children who have experienced childhood trauma, reveal the children develop with significant emotional and behavioral problems (Fisher, Ames, \& Chisholm, \& Savoie, 1997; Sloutsky, 1997). Many of these children have been reported to demonstrate autistic type syndromes (Perry, Pollard, Blakley, \& Baker, 1995). These data suggest that the further away children are from their biological nuclear family when growing up, the more emotional and behavioral difficulty they will have in life. That is, there is a continuum where problems increase. It seems the more sterile the living environment with respect to the development of relationships, the greater the chance that children will develop emotional and behavioral problems. Therefore, with all things 
being equal, it seems that the biological nuclear family is the best place for children to be raised. Second to the natural family, the grandfamily may be the best place to raise children; then other family members; nonrelative foster families; group homes, and, finally, orphanages. However, unless specific interventions are implemented in non-nuclear family living arrangements, children in these situations may live largely unproductive lives or fail to live very long at all.

These children in relative and nonrelative foster care tend to evidence significant behavioral problems in school (Dubowitz, Feigelman, \& Zuravis, 1993). Moreover, the problems these children experience frequently are unidentified, but when they are, little in the way of intervention assistance is provided (Dubowitz et al., 1994).

Although placing children with relatives is seen as ideal when they are removed from the care of their parents, there is little empirical data to support this practice. In general, children in kinship care experience very high levels of behavioral and emotional problems (Dubowitz et al., 1994). These researchers used the Child Behavior Checklist (Achenbach, 1991) in a study of 
relative foster care and found that 26 percent of the children in their study had clinically significant levels of behavior problems. This percentage is markedly more than the 10 percent clinical frequency found in the normative population sample (Achenbach, 1991). With nonrelative foster children, the clinical significance has been reported at 46 percent (McIntyre \& Keesler, 1986).

The severity of foster children's behavioral problems is often associated with prenatal drug exposure and neglect and it becomes an exhausting task for relatives to provide love and consistent parenting to these needy children. There are some differences in how relative and nonrelative foster parents view their charges. Relatives seem to see these children in a more positive light than nonrelatives. However, it may be that relatives simply deny the behavioral problems because of their biological linkage to the children (Berrick et at., 1994). Although the aforementioned may be viewed as pejorative by some, it appears that because the relatives see these children in a positive light, they will tend to be more willing to work with them and maintain the caregiving relationship over an extended period of time. This ensures greater 
stability of the home environment, a necessary component for proper child development.

With respect to school functioning, Dubowitz et al., (1994) found, in their sample of children living with a variety of relatives, the children scored significantly below their peers on nationally standardized measures of reading and math. Most foster children living with relatives were rated below their peers in all academic areas assessed. They evidenced depressed cognitive skills on the Cognitive Abilities Test. They also were rated below average in cognitive functioning, problem solving, reasoning skills, and listening comprehension by their teachers. These children also are more frequently retained at least one grade and receive special education services. It is discouraging to note that even when compared to their inner-city peers who face similar poverty, unstable home environments, and inconsistent parenting, teachers often rated the performance of children in kinship care very poorly (Dubowitz et al., 1994).

In other studies utilizing anecdotal data only, it was ascertained that children living in the care of their grandparents experience significant school related problems (Edwards, 1996a). 
Teachers, guidance counselors, principals, and school psychologists report that grandkin take up much of their time. Grandfamilies make up from seven to ten percent of the school population in low socioeconomic status schools where many of the children are provided free lunch. Yet, students of these grandfamilies account for 70 percent of school personnel time when it comes to dealing with daily problems (Edwards, 1996a).

One child missed several days of school because she stayed home to care for her sick grandmother, fixing her meals and helping her around the house. Another youngster often skipped classes to return home to protect his grandmother's house from his drug-dependent mother's attempts to steal from the home.

Grandkin are often brought to the attention of school personnel because they lack motivation, disrupt their classes, and function poorly in the academic arena. School services and interventions for these children are sundry but successively unsuccessful because they do not address the underlying problems of insecure attachments and the concomitant inability to establish appropriate social networks. 
In that grandparents are ordinarily often more physically fragile, sicker, and older than the typical parent, they may have less energy to assist children with respect to school work and related problems and issues. In addition, supergrands may have a more difficult time finding transportation to the school, preventing them from meeting with teachers and actively involving themselves in the child's education. All of these issues can foster a difficult school and educational experience for grandkin, particularly when the children also have to deal with the loss of their parents and, perhaps, other siblings.

\section{Theoretical Bases for the Study}

The present study is grounded in the conceptual framework of attachment and social support theory. As previously noted, vertical and horizontal attachment relationships particularly affect a child's development.

Ainsworth (1991) provides a cogent discussion of attachment theory and child development. Synchronous exchanges transpire between children and adults in vertical attachments. When synchrony in this context is mentioned, it refers to the reciprocal 
association between the caregiver and child that allows for an accurate fit between the child's and the caregiver's behavioral characteristics. If you have an emotionally loving and expressive child with a distant mother, there is a lack of a good fit and problems may arise (see also Hartup,1989).

Conversely, if you have an active mother who enjoys visiting friends, taking her children to the park, enrolling them in extracurricular and sports activities, but who has a passive, resistant child, this also leads to a lack of synchrony or failure to have a good fit. Not only is the attachment process crucial for the child, it is also a significant means of developing parents' emotional and instrumental patterns of behavior in relationship to the child (Cairns, 1972). Since supergrands are not able to establish these behavioral patterns with their grandkin early in life, when the grandfamily is formed, discord and dysfunction can easily erupt. In addition, interruptions in grandkin's attachment processes, whether physical or emotional, may also disturb the child's ability to relate to all significant adult figures (Edwards, in press). Additionally, inadequate or insecure horizontal attachments are implicated in the inappropriate development of children. 
Horizontal relationships form the basis for social interactions among friends. When grandchildren are uprooted from the biological parents or when they develop in unstable home environments, they frequently fail to learn the expertise necessary to establish appropriate horizontal relationships. Therefore, they may lack the skills to establish and maintain proper and constructive friendships.

The breakdown of the nuclear family that brings about the phenomenon of grandfamilies often results in children developing insecure vertical and horizontal attachments. Again, individuals who develop deficient attachment relationships in childhood tend to experience social and emotional problems throughout their lives, principally in the context of this study, school functioning.

\section{Impact of Attachment and Social Support on Students}

Researchers have shown that the emotional quality of vertical relationships (as previously presented) is strongly related to a child's ability to function appropriately in school before first grade, intelligence at age six, and school achievement at age 12 . The authors controlled for SES, mother's IQ, and the child's preschool IQ 
(Estrada, Arsenio, Hess, \& Holloway, 1987). Further research

findings show vertical and horizontal support relationships can predict achievement longitudinally from Grades three through five and from five through seven (Dubow, Tisak, Causey, Hryshko, \& Reid, 1991).

It is unclear how emotional vertical relationships influence children's intellectual functioning. A cogent suggestion is that children who are securely attached may be strongly stimulated to develop and practice problem solving skills. They inculcate, via the vertical attachment process, a disposition that views help from others as positive. Children with secure vertical attachments undoubtedly feel that they have a stable home base from which to leave and return without fear of harm. From this base they can explore, assimilate, adapt, and learn from their diverse experiences (Edwards, in press; Hartup, 1989). Given the aforementioned, the design of this study is grounded in the theoretical framework of the attachment--social support continuum. It would seem that without the appropriate and secure vertical and horizontal attachment relationships that allow for the development of support 
systems as discussed earlier, grandkin will tend to flounder in school.

There is an accumulation of research studies that suggests social support can prevent or reduce the amount of stress and stress symptomatology individuals undergo (Antonucci, 1990; Hoffman, Ushpiz, \& Levy-Shiff, 1988; Levitt et al, 1994). Social support is defined in terms of instrumental and emotional support. When individuals make tangible assistance available to others in their social network, this is defined as instrumental support. Emotional support occurs when individuals make available affective assistance to others in their social network.

With splintered social networks, the effect is a lack of social support for grandfamilies. As a consequence, there is little help available to grandparents to buffer the stress of parenting their needy and difficult grandkin. One can thus understand the reasons why supergrands tend to experience stress that results in heightened illness, depression, anxiety, alcoholism, and increased smoking (Burton, 1992).

All of the noted concerns can foster a problematic school and educational experience for grandkin, particularly when they also 
have to deal with the loss of their parents and, perhaps, their siblings. Given the additional resultant stress, supergrands who had a difficult time raising their own children are often not better prepared to raise their grandkin. Nonetheless, supergrands may be some of the best caregivers for their grandkin when the latter's parents are unable to care for them because of their close biological linkage. Yet, both supergrands and grandkin receive little support from anyone; grandkin also develop with insecure attachments. The result is that they have problems functioning in areas necessary for proper school adjustment. 
CHAPTER III

\title{
RESEARCH DESIGN AND METHODOLOGY
}

\author{
Introduction
}

The purpose of this study was to determine whether grandkin experienced a greater number of behavioral and emotional problems than their peers who lived in single- or dualparent biological families. An additional purpose was to determine whether grandkin occupied more school personnel time due to problematic functioning. This chapter describes the methodology, instrumentation, research design, and statistical analyses utilized in this study.

\section{$\underline{\text { Sample }}$}

The sample of schools in this study was drawn from the Broward County (Florida) public school system, the fifth largest school district in the nation. The school district enrolls some 200,000 students who attend 195 school sites. 
Initially, ten elementary schools were randomly selected from within the school district. The intent was to obtain a minimum of 100 grandkin in grades three through five, who had been raised by their grandparents for at least one year, to participate in the study. Again, grandkin are children in grandfamilies. However, only at eight of the schools did the principals permit the researcher to collect data on the students. From these eight schools, a final usable sample of 54 grandkin was obtained. In addition, a sample of 54 students matched for grade, gender, and SES was obtained to be used as a comparison group. All families in the study had a yearly income of less than ten thousand dollars. The demographic data for the study group for supergrands, grandkin, parents, and children are found in Tables 1 through 4. 
Supergrands' (Grandparents) Demographic Data

\begin{tabular}{|c|c|c|c|c|c|c|c|}
\hline Marital Status & $\begin{array}{l}\text { Married } \\
21\end{array}$ & $\begin{array}{l}\text { Widowed } \\
12\end{array}$ & $\begin{array}{l}\text { Divorced } \\
10\end{array}$ & \multicolumn{3}{|l|}{$\begin{array}{l}\text { Single } \\
11\end{array}$} & $\begin{array}{l}\text { Total } \\
54\end{array}$ \\
\hline Age & $\begin{array}{l}70+ \\
5\end{array}$ & $\begin{array}{l}60-69 \\
17\end{array}$ & $\begin{array}{l}50-59 \\
16\end{array}$ & $\begin{array}{l}40-49 \\
13\end{array}$ & & $\begin{array}{l}30-39 \\
3\end{array}$ & 54 \\
\hline \multicolumn{2}{|c|}{ Years Raising Grandkin } & $\begin{array}{l}\text { Mean } \\
7.96\end{array}$ & Years in School & & $\begin{array}{l}\text { Mean } \\
11.07\end{array}$ & & \\
\hline $\mathrm{N}=54$ & & & & & & & \\
\hline
\end{tabular}

Biological Parents' Demographic Data

\begin{tabular}{lllll|l}
\hline Marital Status & Married & Widowed & Divorced & Single & Total \\
& 14 & 10 & 7 & 23 & 54 \\
\hline Age & $50-59$ & $40-49$ & $30-39$ & $20-29$ & Total \\
& 4 & 16 & 21 & 13 & 54 \\
\hline
\end{tabular}

Years in School

Mean

12.92

$\mathrm{N}=54$ 
$\therefore$

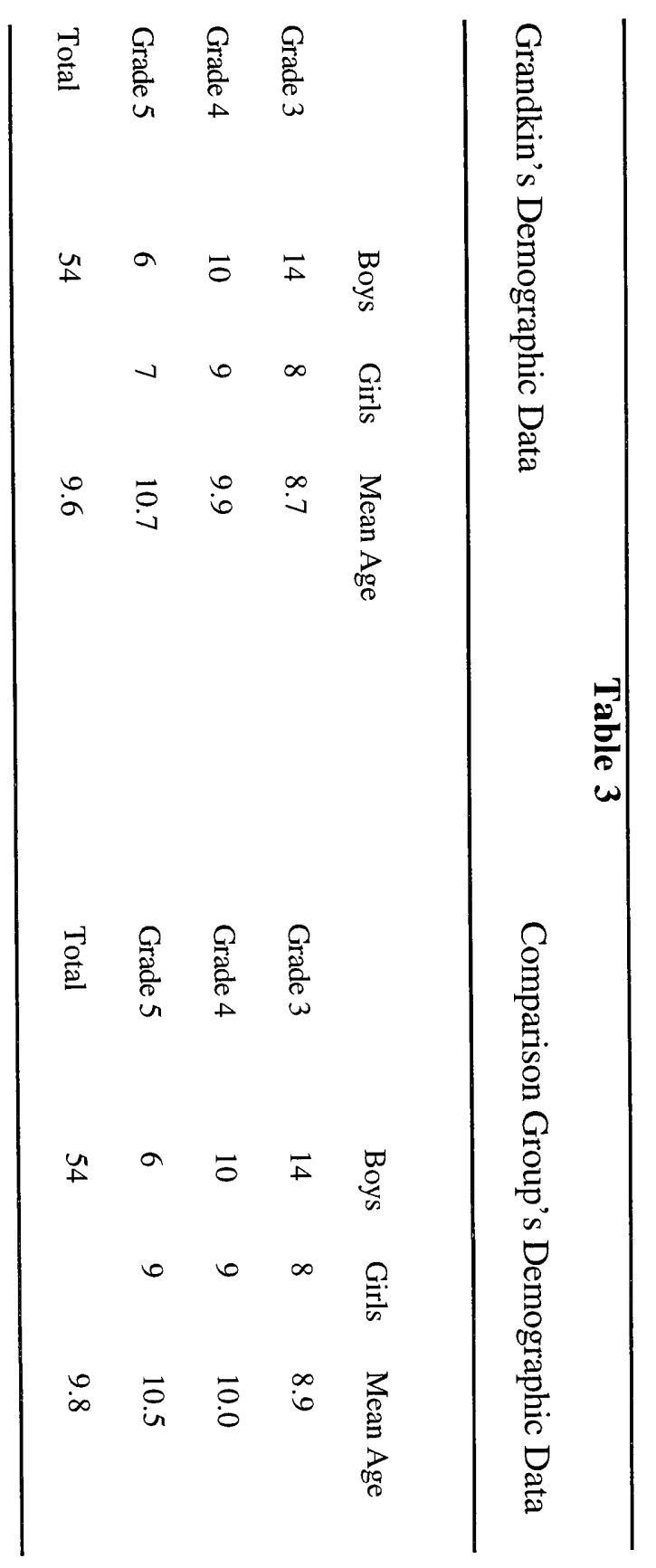




\section{Study Instruments}

Two patterns of behavioral and emotional psychopathology often occur in school age children that tend to negatively influence their functioning. These two patterns, conduct and anxiety disorder, have been termed externalizing and internalizing problems (Achenbach, 1985; Edelbrock, 1979; Quay, 1986). Externalizing patterns of behavior refer generally to aggression, delinquent behavior, and sometimes hyperactivity and difficulty in sustaining attention. The internalizing pattern of behavior indexes anxiety, depression, somatic complaints, and social isolation (McConaughy \& Skiba, 1993).

These patterns of psychopathology have also been described as overcontrolled versus undercontrolled (Achenbach \& Edelbrock, 1978), inhibition versus aggression (Miller, 1967), and personality problems versus conduct problems (Peterson, 1961). Some writers have used the term Negative Affectivity (Finch, Lipovsky, \& Casat, 1989) to symbolize internalizing disorders. However, this term has pejorative connotations and is suggestive of labeling. The first two terms mentioned, externalizing and internalizing, seem to be the most innocuous and empirically tested. As a consequence, to 
identify the problems children in schools exhibit, this study utilized an instrument that provided an excellent measure of internalizing and externalizing problems. This instrument, the Teacher Report Form (TRF), is a component of the Child Behavior Checklist (Achenbach, 1991).

The TRF is designed to obtain teachers' ratings of six too 18year-olds in three domains relevant to this study: Internalizing, Externalizing, and Total Behavior Problems. The general purpose was to obtain reports from teachers of their students' behavioral and emotional problems. This standardized measure accurately provided a clear description of the students' behavior, emotions, and potential academic competencies.

The TRF has 118 items that lead to one of three responses $(0=$ Not True, $1=$ Somewhat or Sometimes True, and $2=$ Very True or Often True) that form the Behavior Problems Scale. The test items indicate presence of overt behavior or state of functioning. A percentile and normalized $\mathrm{T}$-score is provided. The $\mathrm{T}$-scores have a mean of 50 and a standard deviation of 10 . The lowest obtainable $\mathrm{T}$-score is 30 and the highest is 100 . The higher the $\mathrm{T}$-score, the greater the number of behavioral problems the child is thought to 
demonstrate, per the rater. A T-score of 70 , which is at the 98 percentile, separates children from a clinical referred population as opposed to a normal population. The higher the score, the greater the intensity of the problem behavior. Clinically significant scores suggest the child needs professional psychological treatment.

The TRF is well-standardized and sufficiently reliable and valid (Achenbach, 1991). The authors utilized a sample of 1,100 students in grades one through 10 in three large cities (Omaha, Nashville, and Pittsburgh). There were an equal number of boys and girls in the sample. Seventy-seven percent of the sample was White and 23 percent was Black/African-American.

The authors reported mean test-retest reliability of .89 for a period of two weeks, mean test stability of .74 for two months and .68 for four months, and interrater reliability between teachers and teacher aides of .57 . According to the authors the validity of the TRF is related to the substantive content and the congruence of its constructs as evidenced in the available literature on childhood psychopathology. The factor analytic structure of the TRF was obtained via an additional sample of 1,700 students referred for school and mental health services. Using multiple regression, the 
authors were able to obtain a criterion-related validity that consistently indicated that referral status accounted for most of the variance.

Overall, the TRF is an excellent instrument for documenting the behavioral problems of school-age children. The scales have been utilized in over 1500 research studies.

\section{$\underline{\text { Procedures }}$}

Consent to complete the study was obtained from administrators in the school district. Additional consent was needed from the individual school principals. As noted, of the initial ten schools selected, approval to conduct the study at the individual school site was granted from eight principals.

Grandkin were identified using the school system's computer database and teachers' knowledge of their students' family living situation. From the eight schools, a list of 141 grandkin in grades three through five was obtained. This was not an all-inclusive list. It was subsequently learned that there were additional grandkin in the noted grades who were not identified as such. They were missed because their names did not appear in the schools' 
computer database as living with a guardian, and their teachers were not aware of their living situations. Students in the specified grades were selected because at this age, scores on the TRF become very consistent. In addition, teachers find it easier to recognize the behavior and emotional problems of students in these grades.

A combined consent form--demographic survey was sent home with the grandkin for the grandparents to complete. Thirtyone forms were returned indicating that grandparents had consented to participate in the study. Five additional forms were returned indicating that the grandparents did not wish to participate in the study.

Subsequently, 73 forms were sent out again with those grandkin who had not previously returned forms. An additional 32 forms were mailed because the teachers noted that the students most likely would not deliver the forms to their grandparents. Of the 105 forms, another 36 forms were returned with grandparents' signed consent. Two additional forms were returned where the grandparents did not wish to participate in the study. Of the original 141 names, 74 forms were returned, resulting in a response rate of 53 percent. Thirteen of the forms were unusable 
because they did not fit the study characteristics of low income Black/African American grandkin. Altogether, seven forms were returned where grandparents refused consent to participate. As a result, there were 54 grandkin who participated in the study.

A comparison group of 54 students was selected from the same schools the grandkin attended using stratified random sampling. These students were selected to match the grandkin study group based on gender, grade, and income levels. Consent forms were sent home with the children until the matched group of 54 students was obtained. Overall, 97 of these forms were sent home. The response rate was 56 percent. The major difference between the two groups was that the grandkin lived in grandfamilies and the students in the comparison group lived with one or two biological parents. The comparison group was matched for grade, gender, and SES. The students in grandfamilies were compared to their peers on the TRF to, essentially, obtain local norms.

Discipline referrals were collected for students in both groups. Teachers are expected to maintain some type of record of the number of times they refer a student to the school's 
administration and guidance departments because of behavioral problems. They were asked to indicate on the TRF the number of times they referred the students to the schools' administration and guidance departments due to any type of inappropriate behavior in class during a specified two-month period of time.

The independent, or factor variables, for this study were (a) the children in grandfamilies and (b) the children in biological families. The dependent variables were (a) number of discipline referrals to the schools' administration and guidance departments; (b) Internalizing scores on the TRF; (c) Externalizing scores on the TRF; and (d) the presence or absence of clinically significant Total Behavior Problems scores on the TRF.

Given the standardization of the TRF and its normal distribution via a normative population sample, obtaining scores from a comparison group of children provided further support for the distinct differences apparent between grandkin and other children. That is, by securing a comparison group, there will be greater generalizability of the results. Thus, the reason for selecting two groups to participate in the study. 


\section{CHAPTER IV \\ DATA ANALYSIS}

Introduction

In this chapter the statistical analyses of the data are presented. Data were collected utilizing grandparent surveys, Achenbach's Teacher Rating Forms, and teacher plan book records of student discipline referrals. Multivariate and univariate analyses of variance, as well as the Chi-Square test were employed to determine whether grandkin experienced a statistically significant greater number of problems in school when compared to their peers living in single- or dual-parent biological families.

\section{$\underline{\text { Results }}$}

To test the hypotheses that grandkin have more emotional and behavioral problems, as well as discipline referrals, than the comparison group, Multivariate (MANOVA) and univariate (ANOVA) analyses of variance, as well as the Chi-Square test were utilized. The intent was to determine whether there were 
statistically significant differences between the grandkin group and the students from biological families group.

The MANOVA was computed using the grandkin and students in biological families as the independent or factor variables. Internalizing and Externalizing $\mathrm{T}$-scores were used as the dependent variables. The mean $\mathrm{T}$-scores for these variables can be found in Tables 7 and 8. A five-point mean score difference was observed for the Internalizing T-scores. A six-point mean score difference was observed for the Externalizing T-scores. The resulting MANOVA F-test was significant indicating that there was a difference between the two groups. For the main effect of group, $\mathrm{F}$ is 6.53 , which is significant at the $\mathrm{P}<.002$ level. Thus, one must reject the null hypothesis which states grandkin and children from single- and dual-parent households have equivalent Internalizing and Externalizing T-scores on the Teacher Report Form of the Child Behavior Checklist. The results suggest grandkin have a greater number of emotional and behavioral problems than their peers.

The separate univariate F-tests for the variables were significant for both Internalizing and Externalizing T-scores. For the Internalizing $\mathrm{T}$-scores, $\mathrm{F}=7.88$ with $\mathrm{p}<.006$. The statistical 
analysis for Externalizing T-scores shows an F-test score of 9.83, which is a statistically significant result $(\mathrm{p}<.002)$.

The Chi-Square test was utilized to determine whether substantially more grandkin experienced clinically significant behavior problems, per the Total Behavior Problems T-score on the TRF, than students living with their biological parent(s). Pearson's Chi-Square probability yielded a value of 13.076 , which is significant at the $\mathrm{P}<.001$ level. Thus, one must reject the null hypothesis stating that grandkin and children from single- and dual-parent household receive an equal number of clinically significant scores on the Total Behavior Problems T-score on the TRF. The data suggest grandkin had more intense combinations of emotional and behavior problems than their similar peers. In that 44 percent of grandkin had clinically significant Total Behavior Problems T-scores, they also had more intense problems than the normative population of the TRF where only ten percent received clinically significant Total Behavior Problems T-scores.

The Chi-Square test was also utilized to determine whether significantly more grandkin were referred to the schools' administration and guidance departments than similar students 
who lived with biological parent(s). Pearson's Chi-Square probability yielded a value of .738 , which is not significant $(\mathrm{P}>.05)$. Thus, one must fail to reject the null hypothesis stating that an equal number of grandkin and children from single- and dualparent households are referred for discipline problems to the schools' administration and guidance departments. Teachers do not refer grandkin significantly more often due to discipline problems despite the fact they see them as manifesting significant emotional and behavioral problems. Tables 4 through 9 summarize MANOVA, univariate ANOVA Fs, Chi-Squares, levels of significance, and the concomitant statistical analysis of the data.

\section{Table 4}

Means for Internalizing T-scores

$\begin{array}{lll}\text { GROUP } & \text { Mean } & \text { Standard Deviation } \\ \text { Grandkin } & 54.296 & 10.538 \\ \text { Comparison Group } & 49.185 & 8.240 \\ \text { Both Groups } & 51.741 & 9.758\end{array}$




\section{Table 5}

Means for Externalizing T-scores

$\begin{array}{lll}\text { GROUP } & \text { Mean } & \text { Standard Deviation } \\ \text { Grandkin } & 61.722 & 11.107 \\ \text { Students } & 55.426 & 9.720 \\ \text { Both Groups } & 58.574 & 10.859\end{array}$

\section{Table 6}

Effect for Group

Multivariate Tests of Significance $(S=1, M=1 / 2, N=51)$

$\begin{array}{llll}\text { Test Name } & \text { Value } & \text { Exact F } & \text { Sig. of F } \\ \text { Hotellings } & .124 & 6.532 & .002\end{array}$

Note: F statistics are exact. Multivariate effect size and observed power at .0500 Level: Effect Size $=.111 ;$ Power $=.90$

\section{Table 7}

Effect for Group with Univariate F-tests with $(1,106)$ D. F.

Variable

Internalizing- $\mathrm{T}$

Externalizing- $\mathrm{T}$
F

7.884

9.827
Sig. of $F$

.006

.002 


\section{Table 8}

Relationship Between Group Membership

and Clinical Significance of Total Behavior Problems on the TRF

$\begin{array}{lll}\text { Group } & \text { Clinically Significant } & \text { Not Clinically Significant } \\ \text { Grandkin } & 24 \text { (observed) } 44 \% & 30 \text { (observed) } 55 \% \\ \text { Comparison Group } & 7 \text { (observed) } 13 \% & 47 \text { (observed) } 87 \%\end{array}$

* Clinically Significant Total Behavior Problems T-scores per the TRF

Chi-Square

Pearson

Continuity Correction

Likelihood Ratio

Mantel-Haenszel Test for Linear association
Value

13.076

11.583

13.642

12.955
DF Significance

$1 \quad .001$

$1 \quad .001$

$1 \quad .001$

$1 \quad .001$

Note: 1 Minimum expected frequency - 15.500 


\section{Table 9}

Relationship Between Group Membership and Discipline Referrals

$\begin{array}{lll}\text { Group } & \text { Referrals * } & \text { Non-Referrals } \\ \text { Grandkin } & 17 \text { (observed) } 31 \% & 37 \text { (observed) } 69 \% \\ \text { Comparison Group } & 13 \text { (observed) } 24 \% & 41 \text { (observed) } 76 \%\end{array}$

* Discipline Referrals Made to the School's Guidance and Administration Departments

\begin{tabular}{lccc} 
Chi-Square & Value & DF & Significance \\
Pearson & .738 & 1 & .390 \\
Continuity Correction & .413 & 1 & .519 \\
Likelihood Ratio & .740 & 1 & .389 \\
Mantel-Haenszel Test for Linear association & .732 & 1 & .392 \\
& & & \\
Note: 1 Minimum expected frequency - 15.000 & & & \\
\hline
\end{tabular}




\section{CHAPTER V}

\section{DISCUSSION}

Introduction

This chapter provides an interpretation of the results of the study. The discussion emphasizes the difficulties grandkin may encounter due to their emotional and behavioral problems. The problems are addressed as they relate to both the academic and home milieus. In addition, a structured, theoretically-based intervention project is described. The function of the intervention project is to help ameliorate the problems experienced by grandfamilies. Finally, a summary and conclusion of the study are provided.

\section{Findings}

The results of this research study suggest that Black/AfricanAmerican grandkin of low socioeconomic status demonstrate significantly greater levels of behavioral and emotional problems than a comparison group of similar Black/African-American children of low socioeconomic status living in biological families. In 
addition, the former show a greater intensity of problems because considerably more grandkin evidenced clinically significant Total Behavior Problems T-scores. The grandkin in this study also manifested a much higher degree of emotional and behavioral problems than the normative population used for the TRF standardization.

The findings were as expected in that Internalizing, Externalizing, and Total Behavior Problems T-scores on the TRF were elevated. The Externalizing factor on the TRF correlates highly with overt disruptive and defiant behavior problems. The Internalizing factor correlates strongly with disorders of emotion and affect that form the core of anxious behavior. The Total Behavior Problems T-score is a gauge of the intensity of the problem and whether or not professional help from a counselor or therapist is indicated.

Given the findings of this study, grandkin tended to display patterns of behavior that were unruly and unrestrained, as well as introspective and anguished. To a greater extent than their peers, they exhibited nervous behavior and became a disruptive element in class. Yet, the data revealed that their teachers did not refer 
them to the schools' administration or guidance departments at a high rate. It may be that the teachers believed they could control most of these children's emotional and behavioral problems in class. Apparently the teachers believed they may not have received substantial help from the guidance or administration departments if they had referred the grandkin. In addition, the teachers thought, perhaps, they would be perceived in a negative light if they referred too many students from their classes. Moreover, the teachers may have sympathized with the plight of grandkin and may have tried to help them succeed without having the stigma of labels attached to the children. Finally, and what seems most likely, the teachers simply did not maintain very accurate records of the referrals they made to the schools' administration or guidance departments. From discussions with many of the teachers, they acknowledged they often sent their students with discipline problems to the guidance counselor or the assistant principal without a referral or without noting the incident in their planning books.

Many principals, assistant principals, and guidance counselors at the schools also reported that they did not keep accurate records 
as to the number of discipline referrals they received. Moreover, teachers often talked to guidance counselors or administrators about their disruptive children while in the halls or teachers' lounges. Frequently, there was some agreement made to send the disruptive students to the support personnel, but no precise records were kept. Thus, the variable of discipline referrals as operationalized in this study may not be the most exemplary rigorous indicator of grandkin involvement with the schools' administration and guidance departments.

Notwithstanding the sometimes spotty record keeping, the data indicate that of the 31 percent of grandkin and the 24 percent of the comparison group students referred to the schools' guidance and administration departments, grandkin had a higher mean number of referrals. Of the grandkin and comparison group students who were referred, grandkin received three times as many referrals. They spent more time with guidance counselors and administrators.

One axiom in education is that students who evidence disruptive and anxious behavior present a serious problem and significantly impact schools. These types of students occupy an 
extensive and excessive amount of school services and staff time.

Since grandkin fit this mold, they appear, then, to monopolize school personnel's time. In the school environment, extensive behavior problems likely cause significant difficulty for grandkin and teachers. Teachers' time is in high demand. If teachers must spend much of their day focusing on the problems of grandkin, they will have little time left to see to the needs of the class and to provide services to all children.

Discipline problems have become the most disturbing, difficult to deal with, and pervasive issue in schools. It was previously noted that discipline problems in the classroom may be the major reason teachers leave the field early, (i.e., the major reason for teacher "burnout"). Teachers are finding it increasingly difficult to teach students when the class is continually interrupted by disruptive peers such as grandkin. Teachers deal with their behavior problem students in a myriad of ways. They spend a great deal of time developing methods of helping disruptive children. Teachers may utilize structured or programmed behavior management programs, such as assertive discipline, school-wide discipline plans, and structured behavior modification techniques 
on grandkin as well as other individual and groups of students. In addition, many teachers may use their individual resources and characteristics to control the behavior of their students.

Teachers and other school staff often form Child Study Committees and hold numerous meetings to determine how they can reduce the behavior problems of these children. These children are counseled by the school's guidance personnel. They are placed in internal suspension, Saturday school, and external suspension. It often reaches the point that school personnel become eager to remove these behavior problem children from the individual class and school. Teachers refer these children to the schools' Exceptional Student Education (ESE) departments to have them evaluated and hopefully placed in self-contained ESE classes or schools. In addition, in the Broward County school system, teachers are allowed by their union contract to transfer one student per year out of their classroom due to the child's disruptive behavior. Overall, students with discipline problems are viewed with misgivings by the school staff. After implementing many failing interventions, the staff may give up. The students may also 
begin to feel they are helpless, with respect to changing their behavior.

\section{Academic Problems}

Academic problems usual co-occur with discipline and emotional problems in school. There is a high correlation between discipline problems and academic failure (Sawyer \& Dubowitz, 1994). The argument of whether behavior problems cause poor achievement or poor achievement creates discipline problems is an issue that remains unsettled in the field of study. It seems that by simply attending school and being quiet and cooperative, students are often awarded passing grades, solely because they are present and do not disrupt the classroom. Although it is often very difficult to identify which comes first, academic weakness or the behavioral problem, what is generally certain, is that children who evidence behavioral problems also tend to lack motivation and evidence academic difficulty.

Conceivably because their off-task and disruptive behavior does not allow them to concentrate on their school assignments, children with discipline problems exert minimal effort, do not 
begin assignments within a reasonable time frame, and fail to complete assignments altogether. Children in this predicament may frequently function below their assigned grade placements. They are inclined to have problems learning and may have to repeat a grade in school.

Significantly, children with discipline problems are at risk to fail school and to eventually drop out of school. Students who drop out of school are widely recognized as causing serious problems for parents, children, and educators. Children who fail to graduate from school do not achieve to the level of their peers or earn as much as their peers who graduated from school (Weitzman, Kierman, Lamb, Kane, Geromini, Kayne, Rose, \& Alpert, 1985). Adults who have dropped out of school often lead dysfunctional lives. These dropouts are often unemployed and criminally delinquent, characteristics that frequently lead to imprisonment (Weitzman, et al., 1985). Moreover, at one point, 40 to 50 percent of the cost of the federally funded program Aid to Families with Dependent Children (AFDC) was said to be related to school dropouts (Lloyd, 1976). The behavioral problems and academic frustration and failure that grandkin undoubtedly experience in 
school conceivably exacerbate the difficulty they undergo functioning at home, their relationship with their supergrands, and even the supergrands' emotional and physical well-being.

\section{Home Problems}

Given the elevated Internalizing and Externalizing TRF T-scores, as well as the high number of clinically significant Total Behavior Problems T-scores, it is likely that children who live in grandfamilies suffer from a significantly greater amount of stress and stress symptomatology than their peers. This stress can also lead to problems within the home environment.

The data generated by this study support the contention that grandkin generally can be viewed as recalcitrant and stubborn children. Due to the negative events they face early in life, they become hardened to primarily look after their own desires without taking into account the wishes of others. That is, these children often seek immediate gratification. They tend to behave without fully considering how their behavior impacts on others in their environment. Some common complaints people make about these boys and girls is that "he wants to do what he wants, when he 
wants." "She always wants to have her own way." Many of these children are defiant and impulsive, acting without considering the consequences of their actions. In addition, the anxiety and mood swings that are of concern in children with high Internalizing $\mathrm{T}$ scores, cause these children to appear mercurial, temperamental, and, even volatile. They may have excessive fears and repressed emotions, such as panic and anger, that they have difficulty appropriately releasing.

Grandkin with emotional and discipline problems are notoriously difficult to raise. They require extensive amounts of time, money, and energy. As noted previously, supergrands may not have the required time, money, or energy to fill the role of surrogate parents to young children.

Supergrands may feel anger at the situation, which may be transferred to grandkin, even if imperceptibly. The strain resulting from attempting to control their anger and dealing with difficult children can take its toll on grandparents, causing them to have difficulty raising their grandkin. The juxtaposition and coupling of grandparents with difficult children that they must raise will likely 
result in dysfunctional families, or more precisely, dysfunctional grandfamilies.

Moreover, with respect to policy issues, most grandfamilies do not receive governmental financial assistance for raising their grandchildren. Yet, they provide a service the government most likely must provide if the supergrands chose not to keep their grandchildren out of foster care. Without support from social service agencies, particularly financial support, the behavior and emotional problems grandkin experience probably will escalate, and the grandkin may become delinquent and evidence criminal behavior. If these grandkin enter the criminal justice system, they will likely require more public resources than if the grandfamily was assisted when it was first formed.

Despite the problems, the grandfamily may be the best setting to raise grandkin when there is a breakdown in the nuclear family. Supergrands perform an extraordinary service by assuming responsibility for their grandkin. The love these grandmothers and grandfathers have for their grandchildren is strong and linked to a biological bond. Yet, love is only one aspect of parenting. Raising emotionally secure, well-developed, and 
academically strong children call for more than love. At times, though, love is all that supergrands can provide. Supergrands and grandkin may need specific interventions from school personnel, such as teachers, guidance counselors, social workers, and psychologists.

The information garnered from this study resulted in the development of a proposed intervention program for grandfamilies, the Grandfamily School Support Network (GSSN). This project was developed by Edwards (in press; 1996a; 1996b) to help ameliorate the problems grandfamilies encounter. It was learned from this study that grandfamilies, particularly grandkin, had a great deal of difficulty adjusting. They evidenced significant emotional and behavior problems that resulted in high levels of stress. School personnel may be able to attenuate this stress by implementing a project such as the GSSN.

The Grandfamily School Support Network

To mitigate the problematic condition encountered by grandkin and grandfamilies, the GSSN begins with the school's registrar "flagging" the cumulative folder of each grandkin and 
informing a member of the student services staff at the school (guidance, ESE, or school social worker). Most often, either the school psychologist or the guidance counselor should make contact with the supergrand(s) and teacher to determine if there is a need for services at the school and at home. (All school staff can also notify the guidance counselor about grandkin.) If assistance is needed, the grandkin is provided with a classmate who serves as a class buddy. Class buddies are students recommended by teachers because of their reliability and good ego strength. The intent is to find students who can function as class buddies without being influenced to adopt the behavioral problems or characteristics of the grandkin. For their participation as class buddies, these students receive a T-shirt with the school letters on it, roughly like high school athletes receive. The class buddies' role is to help grandkin become socialized to the culture of the school, particularly among the students. The class buddy and grandkin exchange telephone numbers. They sit next to each other in class and spend much of school day together. Class buddies should be sufficiently academically astute so they can assist the grandkin with academic assignments. The intent is for the dyad to form a friendship that 
will mirror a secure horizontal attachment and provide support to both parties. An additional benefit to class buddies is that filling this type of role often results in an increase in self-confidence and leadership skills.

Depending on need, a teacher, paraprofessional, or student service staff member at the school also serves as a surrogate parent on-site and adult mentor with whom the students can meet to discuss their feelings, thoughts, and actions. Based on the grandkin's behavior and academic performance, they are reinforced by their adult mentors. The adult mentors function like the grandkin's parent at the school, safeguarding the child's welfare. Tangible reinforcers are also important as incentives to help the grandkin and their class buddies remain interested in the program. The adult surrogate volunteers can be reinforced for their participation in the project by the school administration via compensation time and special privileges. Overall, this component of the GSSN results in the formation of a school support network for the children.

Some training is needed for the class buddies and surrogates to function capably in their jobs. The class buddies should simply 
be trained to be good friends and role models to help the other member of their dyad behave and achieve better in school. The adult mentors takes the role of parent to the child at the school site. It is important that adult mentors do not spend too much time discussing issues outside the purview of the grandkin's school functioning so as not to encroach on the rights of the biological grandparent(s). They must be careful not to impart their own idiosyncratic values and moral systems in their grandkin.

Brief counseling with the grandchildren/students and supergrand effectiveness training targeted specifically toward supergrands are also important to the success of the program. Brief counseling groups (with grandkin and supergrands separately) may help grandfamilies adjust to their situations. Meeting with grandkin in groups of no more than nine for about 30 minutes for six weeks can teach them to reduce stress and control inappropriate behavior. They may need work on coping with loss and feelings of rejection. In essence, because these children are abandoned at an early age, they develop and mature with attachment issue problems mentioned earlier (see Bowlby, 1973). 
Much of these children's problems arise from their problematic early life history and negative life events. Although all of these issues cannot be resolved in brief sessions, they can learn to compensate for early attachment problems by coping with the stress that is produced. Techniques such as anger management via Aggression Replacement Training (Goldstein \& Glick, Reiner, Zimmerman, \& Coultry, 1987) and social skills training - Think Aloud (Bash \& Camp, 1985) are effective to achieve the aforementioned end. If more in-depth counseling is necessary, referrals to private or public community agencies may be indicated. Collectively, the support network operates to help the grandkin establish trust for adults and peers and to become less oppositional and defiant at school. This alone, however, will not work to improve the grandkin's functioning at school because most of a child's day is spent outside the school environment. If interventions are not attempted in the home as well, the child will continue to struggle.

At the completion of the school day, supergrands can be invited to the school for sessions of supergrand effectiveness training and brief group counseling. Counseling and classes along 
the lines of supergrand effectiveness training tend to ameliorate young children's defiant behavior (Webster-Stratton, 1989). A number of studies suggest the positive effects of parent training to continue for a year or more following treatment (Reid, 1993). Improved child behavior after parent training has been shown to generalize to the preschool classroom (McNeil, Eyberg, Eisenstadt, Newcomb, \& Funderburk, 1991).

Support groups should be established among the grandparents. In addition, there are several community mental health agencies that schedule parent training for parents and grandparents. During these meetings, supergrands should be urged to utilize other family members, friends, or members of their church, to help with homework, transportation, baby-sitting, and to serve as a general backup for the grandparents. Importantly, there is research support for the thesis that parents of children with behavior problems do not spend much time monitoring their children both at school and in peer group interactions outside the school (Ladd \& Golter, 1988; Stevenson \& Baker, 1987).

Some researchers have shown that poor supervision and inept discipline are responsible for about half of the variance in 
antisocial child behavior in the school setting at grade five (Ramsey, Bank, Patterson, \& Walker's study as cited in Reid, 1993). During this time period many children with behavior problems increase the time they spend involved in covert antisocial activities. Thus, supervision is seen as very instrumental in preventing behavioral difficulty. Given these findings, supergrands should be instructed to use their backup helpers or support network for supervision to decrease the risk of current and future antisocial behavior.

A school or community social worker can provide invaluable assistance as part of the GSSN. The social worker or some other professional should serve as a case manager to access outside agencies to aid the supergrands in the surrogate parenting process. Financial aid, outside counseling, and social service assistance for these grandfamilies also can be accessed via the efforts of the social worker. The overall result is that the supergrands also establish a social support network outside the school to buffer the stress of surrogate parenting.

As a whole, providing an environment of academic and social support, both at home and at school, can serve to break the vicious 
cycle of problems and reduce stress symptomatology. The

Grandfamily School Support Network described herein can also lead to improved academic skills for grandkin.

In sum, there is now a large number of grandchildren who become wards of their grandparents due to pejorative circumstances. The grandparents frequently receive little or no assistance from the children's parents. As a result, the existence of grandfamilies can lead to both the children and the grandparents developing problems with their emotional well-being and functioning. The grandchildren tend to manifest emotional and behavioral problems and may suffer academically. The GSSN provides a rich environment of academic and social support, both at home and at school, that may serve to break the vicious cycle of problems and reduce stress symptomatology.

\section{Directions for Future Research}

Although these results were obtained using a low-income, Black/African-American sample, given the similarities of the comparison group, the normative structure and standardization of the TRF, as well as the cross-cultural conceptual underpinnings of 
attachment and social support theory, it is expected that similar results will be found across all populations of similar income. That is, these results should be generalizable among all ethnic groups where their financial resources are similar. As such, these results suggest that grandkin across the ethnic spectrum may manifest many more behavioral and emotional problems when compared with children (with similar family incomes) living with their biological parents. However, the aforementioned will need to be further investigated to determine whether grandkin in all ethnic groups experience more emotional and behavioral problems than their similar peers.

Another important area for future research references the GSSN. The GSSN as a theory-based intervention seems to have some utility in terms of attenuating the emotional and behavioral problems experienced by grandkin. In addition, support provided by the GSSN may help decrease the stress experienced by supergrands. However, the GSSN may need further refining and validation via empirical research to establish its efficacy.

Finally, additional research studies should be conducted to elucidate the causal variable or variables as to why grandkin 
manifest significant emotional and behavioral problems. This research study shows that there is a significant difference between grandkin and their peers living in single- and dual-parent families.

The attachment and social support theory continuum was presented as a plausible explanation for the problems grandkin experience. However, no attachment measure was utilized in this research study. Future research studies should determine whether grandkin experience insecure attachment at a greater level than their peers. These studies should control for childhood trauma or early negative life events to ascertain whether attachment problems or some other variable (perhaps trauma) is responsible for most of the variance in grandkin's emotional and behavioral problems.

\section{$\underline{\text { Conclusion }}$}

The problems that are part and parcel of grandfamilies have been extensively presented in this study. Supergrands often try their best but, undoubtedly, need additional assistance and specific intervention strategies to be able to properly care for their grandchildren. Grandkin tend to display significant behavioral and 
emotional problems that cause them to occupy excessive amounts of teachers' time and school services. However, these grandkin often do not show much improvement. They may benefit from some type of structured theory-driven intervention from school personnel.

Their problems notwithstanding, grandfamilies may be the best place for grandkin because of the close biological relationship with supergrands. However, both grandkin and supergrands require help, perhaps via a program such as the theory-based GSSN, if they are to function adequately at home and at school. These results indicate that the practice of education in schools must change to allow for the development and provision of social support procedures in schools. When there is a breakdown of the nuclear family, the children involved encounter stress. Establishing social support procedures in schools will serve to buffer the stress experienced by grandkin, foster children, children in kinship care, and, frankly, all children. 


\section{CHAPTER VI}

\section{A CASE STUDY}

\section{Introduction}

A case study is presented that describes the problematic school functioning of one grandkin. It also presents a vivid description of the background, current status, and environmental interactions of the grandkin and his grandfamily. The variables of attachment and social support as well as emotional and behavioral problems are clearly delineated. In addition, the case study provides the reader with information on the real-life travails endured by grandfamilies. Finally, the case study provides useful anecdotal data to illustrate and support the general statistical findings of the overall study.

William (not his real name) is a nine-year eight-month-old Black/African-American student who is in the fourth grade. He is currently enrolled in a dropout prevention class at the school due to his academic weaknesses. He is also said to be exhibiting behavior problems at school. He is receiving counseling and 
medical management from a community mental health agency

external to the school system because of his behavioral difficulty.

\section{Evaluation Instruments}

1. Wechsler Intelligence Scale for Children Third Edition (WISC-III)

2. Woodcock-Johnson Psycho-Educational Battery-Revised Tests of Achievement (WJ-R)

3. Bender Visual Motor Gestalt Test (BVMGT)

4. Achenbach Teacher Report Form (TRF)

5. Parent, Student, and Teacher Interview

6. Student Classroom Observation

\section{Background Information}

William resides with his paternal grandmother in Broward

County, Florida. His father sporadically visits the home. His grandmother is in the 60 to 69 age range. She indicated that she did not graduate from high school. Her common law husband died before William was born. No other family members live in the home. However, William has two sisters who live elsewhere within the county. He has very little contact with them. He has 
intermittent contact with his father. He has no contact with his mother. William gets along well with his father and grandmother. $\mathrm{He}$ is said to be closest to his grandmother, among all family members.

William has been living with his grandmother since he was eight months old. His grandmother indicated that William may have been prenatally exposed to drugs. It is generally accepted that children exposed to drugs prenatally are at risk to develop difficulties in school and in life. There is evidence to suggest they also experience academic and behavioral weaknesses. The county's social service agency removed him from the care of his biological parents due to parental neglect. Reportedly, he was not properly fed or cared for appropriately.

William weighed eight pounds and four ounces at birth. However, prior to his reaching his eighth month of life, he was hospitalized on three occasions because of nutrition problems leading to his becoming seriously underweight. This can also result in learning difficulties and problems in school. Before his grandmother received custody, William was said to be failing to thrive. This condition retards development and can be lethal. As a 
young child, William has been subject to high fevers, ear infections, and frequent colds.

William's developmental milestones were delayed. It was reported than he did not sit up until he was one year old. He did not walk until he was older than the age of three years. Toilet training with William lasted through his fourth birthday. He spoke his first words during his third year of life. Currently, he is said to have speech articulation problems.

William has been evaluated by a psychologist and psychiatrist. He is diagnosed with Attention Deficit Hyperactivity Disorder (ADHD) and he is prescribed Ritalin for the condition. He is receiving counseling to help him control his behavior. Otherwise, his current health status was described as good.

\section{Behavioral Perspective}

His grandmother believes William enjoys school. However, he is having difficulty at school because he does not complete his assignments. William is also said to have problems because he is overly active and has temper tantrums. In addition, he has nightmares. He has not been able to fully express the content of 
his nightmares. Nail biting was seen as problematic for William.

There are signs that he is a somewhat anxious youngster. William's interests revolve around playing football and talking. He spends much of his free time with younger children.

His grandmother must often discipline William due to "bad behavior" at school. He also has some difficulty getting along with his friends in the neighborhood. William, at times, can be disrespectful to his grandmother. On these occasions, he will not listen or follow directions. His grandmother uses time-out as the primary method of discipline.

His grandmother expressed her love for William, but she acknowledged that it has been a struggle raising him. His grandmother herself is not well. She has problems with her legs and is nonambulatory. She must use a wheelchair to get around her house. She also expressed a feeling of overall weariness.

Currently, the family earns less than $\$ 10,000$ per year. His grandmother often believes she is struggling to survive economically. William receives free breakfast and lunch at school and the family receives food stamps. William's grandmother does not have a car, nor does she drive. She needs help to get to the 
grocery store, to take William to his counseling appointments, and to any appointments she may have at William's school. As a result, she rarely visits the school, although they live within about a mile of the school. Unless someone from the school visits her at home, his grandmother's only contact with the school is via telephone calls. Moreover, his grandmother does not believe she has the energy or patience to help William with his schooling.

\section{Teacher Interview}

According to his teacher, William has a lovable and endearing personality. He occasionally does as he is supposed to and can be quite funny. At times, his comedic personality relaxes the whole class. He can imitate several television characters. He mimics the character of Steve Urkel, of the television show Family Matters, particularly well. However, he has a difficult time attending to class work. He is also prone to temper outbursts and displays of inappropriate behavior that are disruptive and disturbing to his classmates. In addition, he is fidgety, impulsive, and distractible. William gives up easily and does not complete or turn in many assignments. He is disorganized. His fine motor skills are awkward 
and he does not copy accurately from books or the chalkboard.

Furthermore, William's memory is weak and he does not easily transfer what he has learned from one situation to another. He requires a great deal of praise and encouragement in class.

William was referred to the school's guidance or administration departments at least ten times during a two-month period because of behavioral problems in class. School personnel met together at least six times during this period in attempt to establish intervention help for William. It is estimated that if the teacher truly wished, she could have referred William every other day that he attended school. As such, he occupies an extensive amount of school personnel time. As interventions, he was provided with positive reinforcement and encouragement. He also received small group and individual instruction. He was also allowed to help the physical education teacher as a weekly award for good behavior. In addition, the school was aware he was receiving counseling from the community mental health agency, with whom they occasionally consulted. During this time period, William was also taking Ritalin. However, the interventions seemed to have only a minimal impact on William. He showed 
some progress, both behaviorally and academically, but he continued to be very defiant, disruptive, and dependent in class.

\section{$\underline{\text { Researcher Observations }}$}

William was observed in class and in an individual evaluation session. From the classroom observation, it was ascertained that William was within the average height and weight ranges for his age. He was appropriately attired for school. William was supposed to be completing an independent writing assignment. However, he often left his seat to sharpen his pencil or to talk to different classmates. He would disrupt his classmates and prevent them from completing their work. His teacher needed to remind him several times to sit down. He was also verbally reinforced for remaining in his seat. When he was sitting, he was frequently offtask. He played with his pencil and papers within his desk. He put his head on his desk and began to softly sing a rap song. His teacher utilized three verbal warnings, but William was eventually placed in time-out. Subsequently, for the remainder of the onehour observation session, he needed to be warned only once before he returned to the task at hand. Nonetheless, it was only when he 
went into his small reading group that he exhibited good on-task behavior.

During the individual observation, William was oriented to person, place, and time. He was dressed neatly, but he apparently had some hygiene concerns because he evidenced a body odor. $\mathrm{He}$ maintained fleeting eye contact but appropriate affect throughout the testing. He did not spontaneously initiate conversation with the researcher, but he candidly responded to all questions. William evidenced minor articulation difficulty when he spoke. He mumbled and spoke in an unusually loud voice.

Generally, William's work rate was good. With frequent prompting to do his best, he was diligent and persistent. In addition, he was respectful and followed directions carefully. Overall, William seemed to enjoy this opportunity to interact on a one-to-one basis and his motivation was good.

\section{Intellectual Results}

William's general cognitive ability is within the Low Average range of intellectual functioning, as measured by the Wechsler Intelligence Scale for Children--Third Edition. His overall thinking 
and reasoning abilities exceed those of approximately 10 percent of children his age.

His ability to think with words is comparable to his ability to reason without the use of words. Both William's verbal and nonverbal reasoning abilities also are in the Low Average range. His verbal reasoning abilities are above those of approximately 14 percent of his peers. His nonverbal reasoning abilities are better than those of approximately nine percent of students William's age. William's ability to sustain attention, concentrate, and exert mental control is Low Average. He performed better than approximately 19 percent of his age-mates in this area.

William achieved his best performance among the nonverbal reasoning tasks on the Coding and Picture Completion subtests and lowest score on the Picture Arrangement subtest. His performance across these areas differs significantly, suggesting that these are the areas of most pronounced strength and weakness, respectively, in William's profile of nonverbal reasoning abilities. His weak performance on the Picture Arrangement subtest was below that of most children his age. 
The Coding subtest required William to use a key to associate a series of symbols with a series of shapes and to use a pencil to draw the symbols next to the shapes. A direct test of speed and accuracy, the Coding subtest assesses ability in quickly and correctly scanning and sequencing simple visual information. Performance on this subtest also may be influenced by short-term visual memory, attention, or visual-motor coordination (Coding scaled score $=9$ ). The Picture Completion subtest required William to identify the missing part in each of a series of pictures of common objects and scenes. An indication of his ability in visual discrimination, the Picture Completion subtest assesses the abilities to detect essential details in visually presented material and to differentiate them from nonessential details. Performance on this task also may be influenced by an individual's general level of alertness to the world around him and long-term visual memory (Picture Completion scaled score $=9$ ).

William was required to rearrange each set of randomlyordered pictures into a logical story sequence on the Picture Arrangement subtest. This subtest assesses his abilities to infer cause and effect in social situations and to properly sequence 
events in time. Performance on this task also may be influenced by planning ability and attentiveness to relevant details (Picture Arrangement scaled score $=4$ ).

Overall, his IQ is within the Low Average range of measured intellectual ability. As such, these results suggest that he will need to demonstrate superior effort and motivation to adequately complete most academic tasks.

\section{Table 10}

\section{WISC-III IQ Scores Summary}

SCALE

Verbal

Performance

Full Scale

Verbal Comprehension

Perceptual Organization

Freedom from Distractibility

Note: Mean is 100 and Standard Deviation is 15 


\section{Table 11}

\section{WISC-III IQ Subtest Scores Summary}

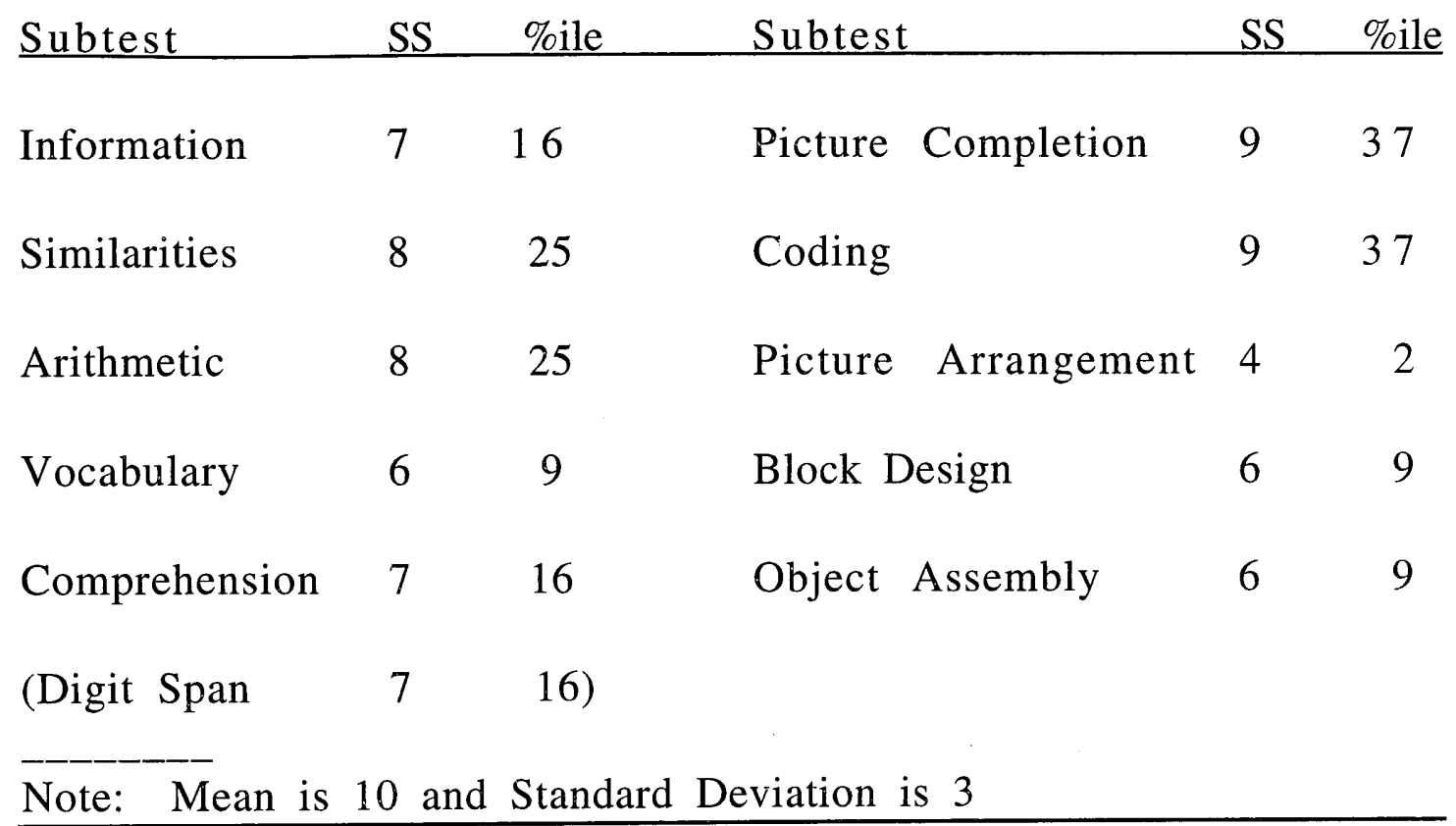

\section{Academic Results}

The results of the Woodcock-Johnson Psycho-Educational Battery-Revised Tests of Achievement (WJ-R) reveal William is functioning below his current grade placement in reading, math, and written language. However, his standard scores are within the expected range given his measured intellectual ability. Math is an area of relative strength and written language is his weakest area. 
On the reading section, William was able to read words such as faster, about, and must. He was unable to read words such as part, knew, and fixed. His weak word identification skills negatively affected his comprehension ability. On the math section, he was able to compute two-digit addition and subtraction problems. He had difficulty with multiplication and division problems. On the written language section, he seemed to have the most difficulty with spelling and word usage. He was able to write his name. It appears William is making slow, but steady, academic progress. Overall, he is functioning well-below his grade level.

\section{Table 12}

WJ-R Academic Broad Scores

Broad Reading

81

11

1.7

Broad Math

90

24

2.3

Broad Written Language

70

02

1.4

Note: Mean is 100 and Standard Deviation is 15 


\section{Table 13}

WJ-R Academic Subtest Scores

Subtest

Letter-Word Identification 79

Passage Comprehension

Calculation

Applied Problems

Dictation

Writing Samples

56

88

87

96

77
Standard Score \%ile

08

1.6

21

2.0

19

2.2

39

2.6

07

1.5

0.2

1.3

Note: Mean is 100 and Standard Deviation is 15

\section{Psychological Functioning}

William obtained a TRF Externalizing T-score of 64,

Internalizing T-score of 57, and Total Behavior Problems T-score of 64. The two T-scores of 64 are in the clinically significant range. The T-score of 57 is not considered clinically significant, although it is above the mean for the TRF's normative population. His Externalizing and Internalizing T-scores are higher than the mean 
score obtained by both the grandkin and comparison groups. Given these findings, William is having extensive behavioral difficulty. However, emotional issues do not appear of significant concern given his nonclinical Internalizing $\mathrm{T}$-score. It appears that William is representative (i.e., fits the profile) of the grandkin who served as participants in the study.

The results of the TRF, observations, testing, and interview indicate William is overly dependent, immature, and insecure. He may believe others view him in a negative light and he seems to accept their perception about him. In fact, he may act to ensure that this becomes a reality. That is, he is very pliant and malleable. William craves a great deal of attention and nurture. $\mathrm{He}$ is a very social youngster who is almost afraid of being alone or isolated. He seems to want his peers to like him to the extent that he will behave in any manner that will get them to notice him, even if he must become the class clown. He tends to seek attention, be it positive or negative. William is highly responsive to praise and encouragement. He will do what he can to please adults, but the reinforcement often must be immediate. Given his weak impulse control, he tends to have difficulty delaying gratification. 
It was also noted that he is diagnosed with ADHD and he demonstrates many of the characteristics associated with the condition. He is fidgety, restless, and has difficulty sustaining attention. He lacks self-esteem and becomes easily frustrated and angry.

William's father does not provide his mother, William's grandmother, with any tangible assistance. The family has relatives within the county, but they also do not provide any help. Consequently, William and his grandmother feel fairly isolated in the world. They depend heavily on each other, but they do not appear able to provide each other with the amount of instrumental and emotional support they both seem to need. William's grandmother indicated she often feels "stressed out" and that she is not doing as much as she should for William. Nonetheless, given her circumstances, she believes she is doing the best that she can to help him achieve in school. William expressed a great deal of love for his grandmother. On occasion, he fears that she may die and leave him all alone. He noted that he would do anything for her, but he believes he sometimes just cannot control his behavior. He 
perceives this as being the reason why, although she wants him to behave and do well in school, he continues to have problems.

This grandfamily is currently just barely functioning, but there are significant indicators of stress and difficulty. Concerns in this grandfamily include financial problems, William's emotional and behavioral problems at home and at school, as well as his grandmother's overall weariness. William has enormous emotional needs for attachment and nurture that in all likelihood exacerbate the dysfunction his grandfamily experiences.

\section{Case Study Summary}

William is a nine-year eight-month-old student who is in the fourth grade. $\mathrm{He}$ is currently enrolled in a dropout prevention class at his school due to his academic weaknesses. He resides with his grandmother in this two-person grandfamily. There are economic, emotional, and academic stressors within the grandfamily. His grandmother has very little energy or patience to raise William adequately given his ADHD diagnosis, behavior, and academic problems. 
William is currently functioning within the Low Average range of measured intellectual ability. Academically, he is functioning below his current grade placement in reading, math, and written language. However, his standard scores are somewhat expected given his Low Average measured intellectual ability. Emotionally, William appears immature and insecure. He also seems to unduly seek out attention, be it positive or negative. The data obtained from this case study suggest William learns at a slower rate than many of his peers. He is making very slow academic progress. Behavioral problems as a partial function of his ADHD condition and attention seeking may hinder his academic functioning. Moreover, this grandfamily seems on the verge of crumbling despite the extensive amount of assistance they are currently receiving from the school and the community mental health agency. It appears they may benefit from a structured and integrated intervention approach, such as the Grandfamily School Support Network described earlier. 
122 


\section{LIST OF REFERENCES}

Achenbach, T. M. (1991). Manual for the child behavior checklist: 4-12 and 1991 profile. Burlington, VT: University of Vermont Department of Psychiatry.

Achenbach, T. M. (1985). Assessment and taxonomy of child and adolescent psychopathology. Newbury Park, CA: Sage.

Achenbach, T. M., \& Edelbrock, C. S. (1978). The classification of child psychopathology: A review and analysis of empirical efforts. Psychological Bulletin, 85, 1275-1301.

Ainsworth, M. D. S. (1991). Attachments and other affectional bonds across the life cycle. In Colin M. Parkes, Joan S. Hinde, \& Peter Morris (Eds.) Attachment across the life cycle (pp. 33-51). London, England: Tavistock/Routledge.

Anglin, M. D. (1990). Drug-abuse treatment to ameliorate negative family and childhood effects of parental drug abuse. In conference proceedings, Raising children for the twenty-first century. Washington, DC: American Enterprise Institute. 
Antonucci, T. C. (1990). Social supports and social relationships.

In R. H. Binstock \& L. K. George (Eds.), The handbook of aging and the social sciences, (3rd ed, pp. 205-227). Orlando, FL: Academic.

Barry, J. (1997) The granny movement: A dispatch from the trenches. The Miami Herald. November 13, 1-2f.

Bash, M. S., \& Camp, B. W. (1985) Think aloud: increasing social and cognitive skills -- A problem-solving program for children. Champaign, IL: Research.

Berrick, J. D., Barth, R. P., \& Needell, B. (1994). A comparison of kinship foster homes and foster family homes: Implications for kinship foster care as family preservation. Children and Youth Services Review, 16, 33-63.

Bowlby, J. (1973). Attachment and loss: Separation (Vol. 2.). NY: Basic.

Brinkley-Rogers, P. (1997). A growing trend: Minority elderly caring for grandkids. The Miami Herald. December 13, 2 BR. Brown, G. I., \& Harris, T. (1978). Social origins of depression. NY: Macmillan. 
Buckner, K., \& Jones, L. (1990). In search of strong administratorsa worthy investments. NASSP Bulletin, $\underline{74}, 20-25$.

Burton, L. M. (1992). Black grandparents rearing children of drug-addicted parents: Stressors, outcomes, and social service needs. The Gerontologist, $\underline{32}$, 744-751.

Cairns, R. B. (1972). Attachment and dependency: A psychobiological and social-learning synthesis. In J. L. Gewirtz (Ed.), Attachment and dependency (pp. 1-251). Washington, DC: V. H. Winston and Sons.

Calabrese, R. L. (1991). Effective assistant principals: What do they do? NASSP Bulletin, 75, 51-57.

Calabrese, R. L., \& Tucker-Ladd, P. R. (1991). The principal and the assistant principal: A mentoring relationship. NASSP Bulletin, 75, 67-74.

Cassidy, J. (1988). Child-mother attachment and the self in sixyear-olds. Child Development, $\underline{59}$, 121-134.

Cherlin, A., \& Furstenberg, F., Jr. (1986). The new American grandparent. NY: Basic.

Colon, F. (1978). Family ties and the child placement. Family Process, $17,289-312$. 
Commission on Precollege Guidance and Counseling (1986).

Keeping the options open. NY: College Entrance

Examination Board.

Doucette-Dudman, D., \& LaCure, J. R. (1996). Raising our children's

children. Minneapolis: Fairview.

Dubow, E. F., Tisak, J., Causey, D., Hryshko, A., \& Reid, G. (1991). A

two-year longitudinal study of stressful life events, social support, and social problem solving skills: Contributions to children's behavioral and academic adjustment. Child Development, $\underline{6} \underline{2}, \quad 583-599$.

Dubowitz, H., Feigelman, S., Harrington, D., Starr, R., Zuravin, S., \& Sawyer, R. (1994). Children in kinship care: How do they fare? Children and Youth Services Review, 16, 85-106.

Dubowitz, H., Feigelman, S., \& Zuravis, S. (1993). A profile of kinship care. Child Welfare, $\underline{72}$, 153-169

Dubowitz, H., \& Sawyer, R. (1994). School behavior of children in kinship care. Child Abuse and Neglect, 18, 899-911. Edelbrock, C. (1979). Empirical classification of children's behavior disorders: Progress based on parent and teacher ratings. School Psychology Digest. $\underline{8}, 355-369$. 
Edwards, O. W. (In press). Helping Grandkin--grandchildren raised by grandparents: Expanding psychology in the schools. Psychology in the Schools.

Edwards, O. W. (1996a). The Grandfamily Intervention Project.

Paper presented at the annual conference of the Florida Association of School Psychologists, Ft. Lauderdale, FL.

Edwards, O. W. (1996b). The grandfamily school support network. NASP Communiqué, 2 5, (2), 16.

Elam, S. M. \& Rose, L. C. (1995). The 27th annual Phi Delta Kappa/Gallup Poll of the public's attitudes toward the public schools. Phi Delta Kappan, 77, 41-56..

Estrada, P., Arsenio, W. F., Hess, R. D., \& Holloway, S. D. (1987).

Affective quality of the mother child relationship:

Longitudinal consequences for children's school-relevant cognitive functioning. Developmental Psychology, 23, $210-$ 215. 
Finch, A. J. Jr., Lipovsky, J. A., Casat, C. D. (1989). Anxiety and depression in children and adolescents: Negative affectivity or separate constructs? In P. C. Kendall \& D. Watson (Eds.), Anxiety and depression: Distinctive and overlapping features (pp. 171-202). NY: Academic.

Fischer, L. R., (1983). Transition to grandmotherhood. International Journal of Aging and Human Development, 16, $67-78$.

Fisher, L., Ames, E. W., Chisholm, K., \& Savoie, L. (1997). Problems reported by parents of Romanian orphans adopted to British Columbia. International Journal of Behavioral Development, 20 , 67-82.

Gold, Y., \& Roth, R. A. (1993). Teachers managing stress and preventing burnout. Washington DC: Farmer.

Goldstein, A. P., Glick, B., Reiner, S., Zimmerman, D., \& Coultry, T. M. (1987). Aggression replacement training: A comprehensive intervention for aggressive youth. Champaign, IL: Research.

Gorton, R. A. (1987). Improving the assistant principalship: The principal's contribution. NASSP Bulletin, 71, 1-4. 
Hardesty, P. H., \& Dillard, J. M. (1994). The role of elementary school counselors compared with their middle and secondary school counterparts. Elementary School Guidance and Counseling, 29, 83-91.

Harrington, R., Fudge, H., Rutter, M., Pickles, A., \& Hill, J. (1991).

Adult outcomes of childhood and adolescent depression:

Links with antisocial disorders. Journal of the American Academy of Child and Adolescent Psychiatry, 30, 434-439.

Harlow, H. F., (1959). Love in infant monkeys. Scientific American, 200, 68-74.

Harlow, H. F., \& Suomi, S. J. (1971). Production of depressive behaviors in young monkeys. Journal of autism and childhood schizophrenia, $1,246-255$.

Hartup, W. W. (1989). Social relationships and their developmental significance. American Psychologist, 44, (2), 120-126.

Hetherington, E. M., Stouwie, R. J., Ridberg, E. H. (1971). Patterns of family interaction and child-rearing attitudes related to three dimensions of juvenile delinquency. Journal of Abnormal Psychology, 78, 160-176. 
Hoffman, S. A., Ushpiz, V., \& Levy-Shiff, R. (1988). Social support and self-esteem in adolescence. Journal of Youth and Adolescence, 17 , 307-316.

Howard, S. (1989). Examining functions within the school counselor role. Texas Association for Counseling and Development Journal, 17, 115-120. Hunter, D. (1990). How to increase assistant principals' involvement in class management. NASSP Bulletin, 74, 4. Johnson, C. L., \& Barer, B. M. (1990). Families and networks among older inner-city blacks. The Gerontologist, $\underline{30}$, 726733.

Johnson, C. L. (1983). A cultural analysis of the grandmother. Research on Aging, 5, 547-568.

Kivett, V. R. (1991). The grandparent-grandchild connection. Marriage and Family Review, 16, 267-290.

Kornhaber, A. (1985). Grandparenthood and the "new social contract." In V. L. Bengtson \& J. F. Robertson (Eds.), Grandparenthood (p. 159-171). Beverly Hills, CA: Sage. 
Kornhaber, A. \& Woodward, K. (1981).

Grandparents/grandchildren: The vital connection.

Garden City, NY: Anchor Press/Doubleday.

Ladd, G. W., \& Golter, B. S. (1988). Parents' management of preschoolers' peer relations: Is it related to children's social competence? Developmental Psychology, 24, 109-117.

Levitt, M. J., Guacci-Franco, N, \& Levitt, J. L. (1994). Social support and achievement in childhood and early adolescence: A multicultural study. Journal of Applied Developmental Psychology, 15, 207-222.

Lloyd, D. (1976). Concurrent prediction of dropout and grade of withdrawal. Educational Psychology Measurement, $\underline{36}$, 983991.

Lubben, J. E., \& Becerra, R. M., (1987). Social support among Black, Mexican, and Chinese elderly. In D. E. Gelfand \& C. M. Baressi (Eds.), Ethnic dimensions of aging (pp. 130-144). NY: Springer.

Magruder, J. (1994). Characteristics of relative and nonrelative adoptions by California public adoption agencies. Children and Youth Services Review, 16, 123-131. 
Maslow, A. H. (1943). A dynamic theory of human motivation.

\section{Psychological Review, 50, 370-396.}

McIntyre, A. \& Keesler, T. Y. (1986). Psychological disorders

among foster children. Journal of Clinical Child Psychology,

4, 297-303.

McNeil, C. B., Eyberg, S., Eisenstadt, T. H., Newcomb, K., \&

Funderburk, B. (1991). Parent-child interaction therapy

with behavior problem children: Generalization of treatment

effects to the school setting. Journal of Clinical Child

Psychology, 20, 140-151.

McConaughy, S. H., \& Skiba, R. J. (1993). Comorbidity of

externalizing and internalizing problems. Journal of School

Psychology, 22, 421-436.

Miller, L. C. (1967). Louisville Behavior checklist for males, 6-12 years of age. Psychological Reports. 21, 885-896.

Miller v. Youakim Supreme Court 440 U.S. 125 (1979).

Minkler, M., \& Roe, K. (1993). Grandmother as Caregivers.

Newbury Park, CA: Sage. 
Montalvo, A., Bair, J. H., \& Boor, M. (1995). Teachers'

perceptions of occupational stress factors. Psychological Reports, $\underline{76}, 846$

Morse, C. L., \& Russell, T. (1988). How elementary counselors see their role: An empirical study. Elementary School Guidance and Counseling, 23, 54-62.

Patterson, G. R. (1992). Developmental changes in antisocial behavior. In Ray D. Peters, Robert J. McMahon, \& Vernon L. Quinsey, (Eds.), Aggression and violence throughout the life span (pp. 52-82). Newbury Park, CA: Sage.

Pellicer, L. O., \& Stevenson, K. R. (1991). The assistant principalship as a legitimate terminal career alternative. NASSP Bulletin, 75 , 59-65.

Perry, B. D., Pollard, R. A., Blakley, T. L., \& Baker, W. L. (1995). Childhood trauma, the neurobiology of adaptation, and usedependent development of the brain: How "states" become "traits." Infant Mental Health Journal, 16, 271-291. 
Peterson, D. R. (1961). Behavior problems of middle childhood. Journal of Consulting Psychology 23, 205-209.

Poe, L. M. (1992). Black grandparents as parents. Berkeley, CA: Author.

Quay, H. C. (1986). Classification. In H. C. Quay \& J. S. Werry (Eds.), Psychopathological disorders of childhood (3rd ed., pp. 1-42). NY: Wiley.

Ramsey, E., Bank, L., Patterson, G. R., \& Walker, H. (1993). From home to school to juvenile court: A social interaction model of the path to delinquency. In J. B. Reid Prevention of conduct disorder before and after school entry: Relating interventions to developmental findings. Development and Psychopathology,, , 243-262.

Reid, J. B. (1993). Prevention of conduct disorder before and after school entry: Relating interventions to developmental findings. Development and Psychopathology, $\underline{5}, 243-262$ Sawyer, R., \& Dubowitz, H. (1994). School performance of children in kinship care. Child Abuse and Neglect, 18 , 587597. 
Scoggins, J. A., \& Bishop, H. L. (1993). A review of the literature regarding the roles and responsibilities of assistant principals. Paper presented at the annual meeting of the Mid-South Educational Research Association (22nd, New Orleans, LA, November 10-12.

Sloutsky, V. M. (1997). Institutional care and developmental outcomes of 6- and 7-year-old children: A contextualist perspective. International Journal of Behavioral Development, 20, 131-151.

Smith, J. A. (1987). Assistant principals: New demands, new realities, and new perspectives. NASSP Bulletin, 71, 9-12. Sroufe, L. A., \& Fleeson, J. (1986). Attachment and the construction of relationships. In W. W. Hartup \& Z. Rubin (Eds.), Relationships and development (pp. 51-72). Hillsdale, NJ: Erlbaum.

Stevenson, D., \& Baker, D. P. (1987). The family-school relation and the child's school performance. Child Development, $\underline{58}$, $1348-1357$. 
Strom, R. D., \& Strom, S. K. (1993). Grandparents raising grandchildren: Goals and support groups. Educational Gerontology, 19, 705-715.

Thomas, J. L. (1986). Age and sex differences in perceptions of grandparenting. Journal of Gerontology, 41, 417-423.

Toth, S. L. \& Cicchetti, D. (1996a). Patterns of relatedness, depressive symptomatology, and perceived competence in maltreated children. Journal of Consulting and Clinical $\underline{\text { Psychology, }} \underline{64}, 32-41$.

Toth, S. L. \& Cicchetti, D. (1996b). The impact of relatedness with mother on school functioning in maltreated children. Journal of School Psychology, 34, 247-266.

Troll, L. (1983). Grandparents: The family watchdogs. In T. Brubaker (Ed.), Family relationships in later life (pp. 63-74). Beverly Hills, CA: Sage.

U.S. Bureau of the Census. (1990). Marital Status \& living arrangements, (March, 1993, pp. 20-478). Washington, DC. Government Printing Office. 
Webster-Stratton, C. (1989). Systematic comparison of consumer satisfaction of three cost-effective parent training programs for conduct problem children. Behavior Therapy, 20 (1), 103116.

Weitzman, M., Kierman, L. V., Lamb, G. A., Kane, K., Geromini, K. R., Kayne, R., Rose, L., \& Alpert, J. J. (1985). Demographic and educational characteristics of inner city middle school problem absence students. American Journal of Orthopsychiatry, 55, 378-383

Wilgus, E., \& Shelley, V. (1988). The role of the elementary school counselor: Teacher perceptions, expectations and actual functions. The School Counselor, $\underline{35}, 259-266$. 
OLIVER W. EDWARDS

7813 W. Kismet Street

Miramar, FL 33023

\section{EDUCATION}

Ed.D., Educational Administration and Supervision -

Psychology Cognate, April, 1998. Florida Education

Fund Doctoral Fellow, Florida International University

Dissertation Topic: Grandfamilies--Grandchildren

Raised by Grandparents: Impact on Students and

School Services.

Ed.S., School Psychology - University of Florida, August, M.Ed., 1989. Research Topic - Agreement Among School Psychologists in Diagnosing Potentially Emotionally Handicapped Children.

BA, Psychology - Florida International University,

December, 1986. Research Topic - Parental

Expectations and Academic Performance in Children of West Indian Descent Living in America.

\section{QUALIFICATIONS}

State Certified in Educational Administration and Supervision

State Licensed School Psychologist

State Certified School Psychologist

Nationally Certified School Psychologist

\section{EDUCATIỐNAL EXPERIENCE}

Practicing school psychologist with the School Board of Broward County: Performed psychological evaluations and reevaluations; provided counseling, consultation; and intervention development services; practiced in elementary, middle, and high schools. 


\section{EDUCATIONAL EXPERIENCE - continued}

Director and developer of the Grandfamily School Support Network (GSSN). The GSSN is a grant funded program designed to help children being raised by their grandparents perform better at school.

Served as the initial school psychologist at the CHARLEE Assessment Center; a grant-funded assessment and treatment program for students (11-17) run by both the School Board of Broward County and Broward County Social Services Division. Assessed clients as well as provided individual and group counseling.

Full-time 1200 clock hour internship in School Psychology, School Board of Broward County: Performed evaluations and reevaluations; provided consultation and worked in elementary, middle, high schools, and Exceptional Student Education Center settings.

Practicum in School Psychology 160 clock hours, School. Board of Alachua County: The experience involved rotating among the different school settings and school psychologists within the county.

\section{UNIVERSITY EXPERIENCE}

Assistant to the Associate Dean of the Graduate School of the University of Florida, (1987-1988). Served as Recruitment Coordinator; coordinated the efforts of over fifty recruiters and their visits to colleges and universities as they attempted to increase the graduate minority student enrollment at the University of Florida. 


\section{PROFESSIONAL EXPERIENCE}

Technology Facilitator for area student services: Developed technology plans, taught computer application skills, and served on district advisory committees. Served on the committee established to appropriately utilize $\$ 150,000$ of technology funds for the district.

\section{GRANTS}

Research Grant -- Citibank Educational Foundation

Florida Education Fund Doctoral Fellowship

Delores Auzenne Fellowship

\section{HONORS/AWARDS}

Dean's List, Florida International University Graduate Dean Award, Graduate School, University of Florida Commendation Medal, United States Army

\section{AFFILIATIONS}

American Educational Research Association National Association of School Psychologists Florida Association of School Psychologists Broward Association of School Psychologists

\section{PUBLICATIONS}

Edwards, O. W. (In Press). Helping grandkin - grandchildren raised by grandparents: Expanding psychology in the schools. Psychology in The Schools.

Edwards, O. W. (1996). The Grandfamily Intervention Project. Paper presented at the annual conference of the Florida Association of School Psychologists. 


\section{PUBLICATIONS - continued}

Edwards, O. W. (1996). The grandfamily school support network (GSSN). NASP Communiqué, 25, (2), 3.

Skaruppa, C., Boyer, A., \& Edwards, O. (1997). Tuition reimbursement for parents' unilateral placement of students in private institutions: Justified or not? West's Education Law Reporter, 114, (2), 353-358. 